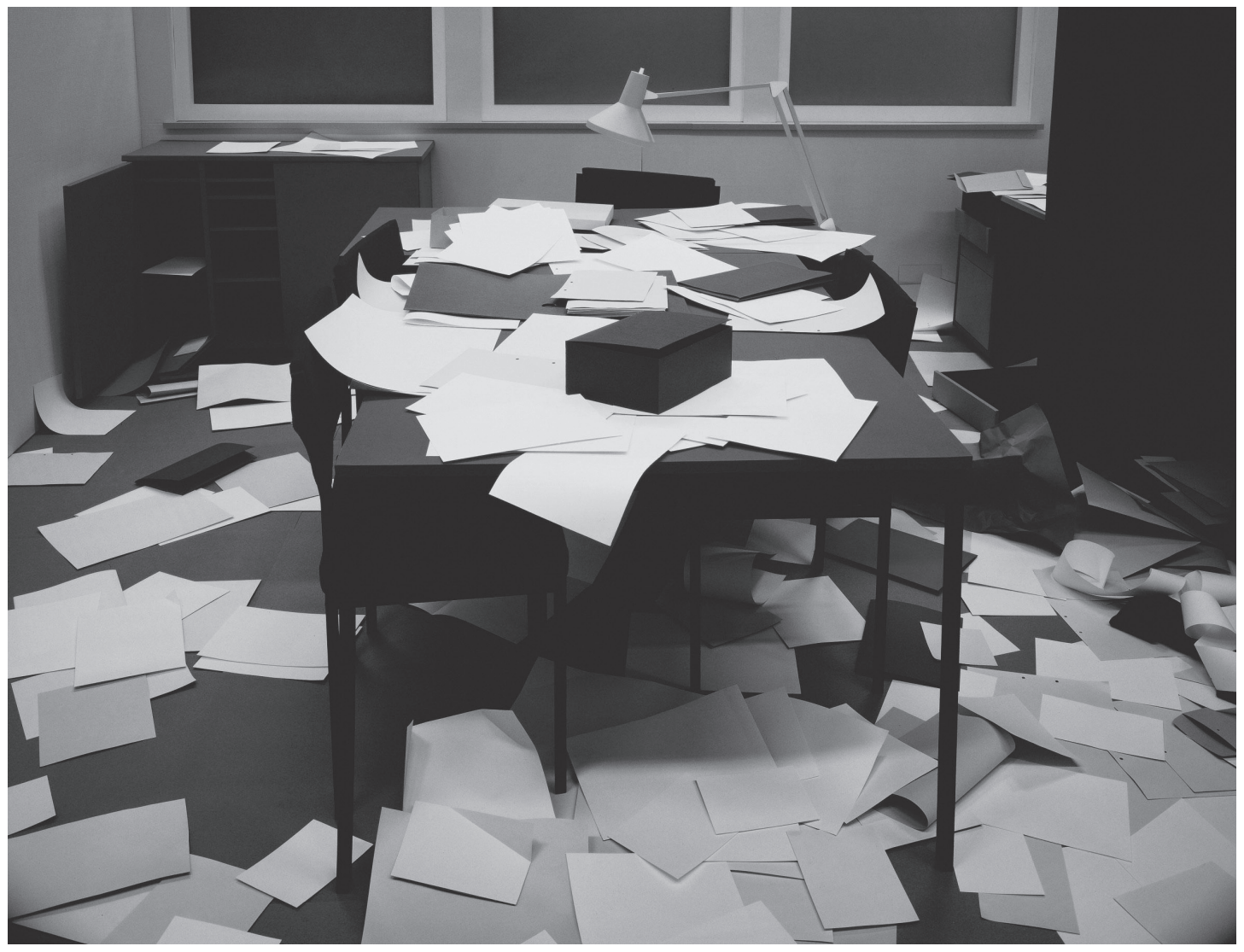




\section{Thomas Demand e suas alegorias da intenção; "exclusão" em Candida Höfer, Hiroshi Sugimoto, e Thomas Struth}

Tradução

\section{Thomas Demand's allegories of intention: "exclusion" in Candida} Hofer Hiroshi Sugimoto, and Thomas Struth.

palavras-chave: fotografia contemporânea, antiteatralidade, absorção, teoria da arte, Michael Fried

keywords: contemporary photography, anti theatricality, absorption, art theory, Michael Fried

Thomas Demand Office, 1995.
Em 2008, com a publicação de Why photography matters as art as never before, Michael Fried retoma as discussões iniciadas em "Arte e objetidade", ensaio de 1967, em especial a ideia de "absorção" ou antiteatralidade da arte, suposta característica da arte modernista em contraposição à minimalista/literalista. Fried debate a questão da "presença", argumentando em prol da antiteatralidade, considerando a "absorção" como a principal qualidade nos trabalhos fotográficos de Thomas Struth, Thomas Demand, Candida Höfer entre outros, sobretudo no capítulo 9, aqui traduzido. A partir de uma minuciosa descrição e da análise formal das imagens, Fried encontra parâmetros para consolidar seu principal argumento: a capacidade de "absorção" da fotografias.

In 2008, with the publication of Why Photography Matters as Art as Never Before, Michael Fried resumes the discussions initiated in "Art and Objecthood" (1967), in particular the idea of "absorption" or antiteatrality of art, supposed characteristic of Modernist art as opposed to the minimalism/ literalist art. Fried discusses the issue of "presence", arguing for anti-theatricality, considering "absorption" as the main quality in the photographic works of Thomas Struth, Thomas Demand, Candida Höfer among others, especially in chapter 9, translated here. From a detailed description and the formal analysis of the images, Fried finds parameters to consolidate his main argument: the ability of photographs to "absorb". 
Michael Fried nasceu em 12 de abril de 1939, em Nova Iorque, é crítico, historiador de arte e atualmente professor na Universidade Johns Hopkins em Baltimore, Maryland (EUA). A contribuição de Fried para o discurso histórico da arte se deu no debate sobre as origens e desenvolvimento do modernismo, juntamente com Clement Greenberg, T. J. Clark e Rosalind Krauss, desde o início dos anos 1960.

Uma questão chave para Fried é a "absorção" ou antiteatralidade da arte (presente na arte modernista em contraposição à minimalista/ literalista), conceito que ele apresenta em seu ensaio mais conhecido, "Art and objecthood" (Arte e objetidade) de 1967, escrito em resposta ao artigo "Objetos específicos", de Donald Judd, que apresentava em 1965 a nova produção da cena artística norte-americana, que hoje acolhemos sob o termo Minimalismo. No artigo de 1967, Fried critica os objetos de arte minimalista - que denomina de "arte literalista" - pelo que considera sua condição teatral, ou seja, para que o trabalho se realize ele depende da presença do observador e de sua experiência com o objeto no espaço, ao contrário do que acontecia com as pinturas e esculturas modernistas que focavam nas propriedades intrínsecas dos trabalhos. Para Glória Ferreira, responsável pela apresentação da tradução de "Arte e objetidade" de Milton Machado na revista Arte E Ensaios" em 2002, este é um dos "polêmicos e decisivos" textos da crítica de arte dos anos 1960, por evidenciar a "radical diferença na natureza entre o objeto minimal e a obra de arte modernista”.

Esse conceito e o seu oposto - teatralidade $\mathrm{x}$ antiteatralidade -, articulados com a ideia de "presença", foram retomados em escritos posteriores sobre a pintura francesa de meados do século XVIII até Manet e sua geração (anos 1860). A convenção da pintura francesa de 1750 , previa que os personagens deveriam ser representados como se estivessem totalmente absorvidos/absortos pelo que estivessem fazendo, como se nada mais houvesse a sua volta, todos voltados para dentro da pintura. Qualquer indicação de que os personagens estivessem atuando para uma audiência seria considerada teatral e, portanto, um erro. Fried resgata a ideia de teatralidade e seu inverso dos escritos de Denis Diderot e sua definição do tableau como "o uso de motivos e estruturas absorventes para estabelecer a ilusão ontológica de que o observador não existe." ${ }^{2}$ A absorção é então a ficção suprema, o encerramento de um mundo dentro da moldura que não engaja o espectador a participar, excluindo-o da cena, como se a barreira da superfície da imagem
Michael Fried

Thomas Demand e suas alegorias da intenção; "exclusão" em Candida Höfer, Hiroshi Sugimoto, e Thomas Struth

1. Arte \& Ensaios é uma publicação semestral organizada pelo Programa de Pós-Graduação em Artes Visuais da Escola de Belas Artes da Universidade Federal do Rio de Janeiro.

2. FRIED, Michael. Why photography matters as art as never before. New Haven: Yale University Press, 2008, p. 34, tradução nossa. 

relação direta entre atores e público.

3. ALMEIDA, Juliana Gisi Martins de. Fotografia e práticas artísticas: os discursos dos artistas nos anos 1960 e 1970 . Tese de doutorado. Porto Alegre: Universidade Federal do Rio Grande do Sul, 2013, p. 119.

4. WALL, Jeff. Marks of indifference: aspects of photography in, or as, Conceptual Art (1995). In: FOGLE, Douglas (org.). The last picture show: artists using photography 19601982. Minneapolis: Walker Art Center, 2003, p. 32. Apud ibidem, tradução de Juliana G. M. Almeida.
Mais recentemente, o interesse de Michael Fried recai sobre o meio fotográfico. Em meados dos anos 2000, ele começa a pensar e escrever sobre fotógrafos em revistas como Artforum, conforme seu próprio relato na introdução ao livro Why photography matters as art as never before, de 2008. O motivo desse interesse, que antes se dirigia à pintura e à escultura, é sua percepção de que desde os anos 1980 a fotografia começa a ser reconhecida como "algo para ser visto na parede", e passa a ocupar um lugar similar ao da pintura no contexto da arte contemporânea.

Por essa perspectiva, Fried faz um paralelo de sua abordagem com o conceito forma-quadro de Jean-François Chevrier, contrapondo as fotografias ampliadas em grande formato - para serem colocadas na parede e contempladas - às fotografias menores, que podem ser manipuladas ou encontradas em revistas, jornais e livros. O tamanho grande impõe que a experiência se dê com as fotografias na parede em frente ao espectador, permitindo que elas sejam vistas de perto, escrutinadas e estudadas por uma pessoa por vez. Assim, o que se ganha com a escala ampliada, além da presença que impacta, são os detalhes visíveis. De maneira semelhante ao que acontece com a pintura ou a escultura, para Fried, as fotografias de grande formato perdem muito quando publicadas em um livro ou catálogo. Posicionamento que vai ao encontro da tese de Jeff Wall, apresentada no texto "Marks of indifference: aspects of photography in, or as, Conceptual Art", de 1995, em que propõe "uma narrativa histórica e teórica fundada no mesmo pressuposto modernista greenberguiano: a autocrítica e reflexividade como meios para a fotografia atingir sua especificidade, a redução à sua condição necessária e suficiente para se tornar arte modernista.”3 Nas palavras de Wall: "A fotografia não pode encontrar alternativas para a figuração [depiction], como podiam as outras belas artes. Está na natureza física do meio retratar [depict] coisas. Para poder participar do tipo de reflexividade tornada mandatória para a arte modernista, a fotografia só pode colocar em jogo sua própria condição necessária de ser uma figuração-que-constitui-um-objeto.” ${ }^{4} \mathrm{O}$ encontro com Wall é apontado por Fried como fundamental para sua abordagem, pois evidencia algo na fotografia que o interessou por toda sua trajetória: a relação entre o observador e o objeto artístico, como se a fotografia herdasse todo o 
problema da contemplação (beholding). Nesse sentido, dando continuidade à linha teórica que desenvolveu, ele adota para a fotografia seu conceito de antiteatralidade, que aponta como central para o livro Why photography matters as art as never before.

Nessa publicação, ainda inédita no Brasil, Fried apresenta uma justificativa formal e teórica da fotografia de arte desde o final dos anos 1970, argumentando que o uso da grande escala nos artistas escolhidos constitui uma trajetória significativa na arte contemporânea, são eles: Jeff Wall (cujo trabalho é analisado nos capítulos 1, 2, 3 e 8), Cindy Sherman (capítulo 1), Thomas Struth (capítulos 5, 7 e 9), Luc Delahaye (capítulo 6), Thomas Ruff (capítulo 6), Andreas Gursky (capítulo 6), Hiroshi Sugimoto (capítulos 1 e 9), Rineke Dijkstra (capítulo 7), Patric Faigenbaum (capítulo 7), Roland Fischer (capítulo 7), Douglas Gordon e Philippe Parreno (que trabalham com vídeo, mas entram aqui na discussão do capítulo 7), Beat Streuli (capítulo 8), Philip-Lorca diCorcia (capítulo 8), Thomas Demand (capítulo 9), Candida Höfer (capítulo 9), James Welling (capítulo 10), Bern e Hilla Becher (capítulo 10), entre outros. A partir de uma minuciosa descrição e da análise formal, Fried encontra parâmetros para consolidar seu principal argumento: a capacidade de "absorção" das fotografias apresentadas, e retoma a discussão da "presença" argumentando em prol da antiteatralidade. Assim, a exclusão do espectador, ou melhor, a impossibilidade de se penetrar no espaço representado na fotografia é levado em consideração como uma distância crítica.

Para a construção de seu argumento, Fried pontua, a partir das poéticas dos fotógrafos elencados, os elementos constituintes que afirmam sua tese no decorrer do livro. Na articulação dos trabalhos de diferentes artistas, Fried concentra-se em questões específicas e é por este motivo que alguns aparecem em vários capítulos, pois seus trabalhos apresentam mais de uma faceta que interessa ao autor. O capítulo 9, aqui traduzido, intitulado "Thomas Demand e suas alegorias da intenção; "exclusão" em Candida Höfer, Hiroshi Sugimoto e Thomas Struth", é dedicado a demonstrar como: a estranheza ou "desconexão" de Thomas Demand, o rigor compositivo e imaculado dos ambientes de Candida Höfer, a reticência das paisagens de Struth e, por fim, a despersonalização em Sugimoto são estratégicas para manter o observador a essa distância crítica e reflexiva, que impede a ilusão e, logo, a teatralidade.
Michael Fried

Thomas Demand e suas alegorias da intenção; "exclusão" em Candida Höfer, Hiroshi Sugimoto, e Thomas Struth 

contemporânea a partir dos mesmos pressupostos que enunciou para abordar a pintura modernista. Com isso, conecta dois universos imagéticos distintos - apesar de intrinsecamente ligados - afirmando uma linearidade historicamente justificada por uma transferência conceitual. Assim, o autor reafirma anacronicamente a validade de seus argumentos teóricos e reforça o fundamento de sua abordagem da arte - essa que estrutura seu pensamento como crítico ou historiador: a de que a qualidade da fotografia contemporânea está em sua capacidade de negar a literalidade, como já fizeram a pintura e escultura modernista.

Tradução do Capítulo 9 do livro Why photography matters as art as never before, de Michael Fried. New Haven: Yale University Press, 2008. 410 pp.

\section{Thomas Demand e suas alegorias da intenção; “exclusão” em Candida Höfer, Hiroshi Sugimoto e Thomas Struth}

5. Trabalhos recentes sobre Demand incluem: Thomas Demand: photography, catálogo de exposição contendo ensaio de Ralph Rugoff e uma estória de Julia Franck (Bregenz, 2004); Roxana Marcoci,

Thomas Demand, catálogo de exposição com um conto de Jeffrey Eugenides (Nova Iorque, 2005); e Thomas

Demand, catálogo de exposição com ensaio de Beatriz Colomina e uma conversa entre Alexander Kluge e Thomas Demand (Londres, 2006).

6. SOBEL, Dean. Thomas

Demand: the basic facts. In: Thomas Demand, catálogo de exposição. Amsterdam e Aspen, 2001-2002, s/p. Futuras referências a esse ensaio estarão entre parêntesis no texto.
Thomas Demand nasceu em 1964, o que faz dele dez anos mais jovem que Struth, Ruff, e Gursky. ${ }^{5}$ Assim, como estes, Demand estudou na academia de Düsseldorf, mas diferentemente deles sua formação inicial era de escultor, e existe um sentido importante de como uma certa prática escultórica está no cerne de sua fotografia (como tem sido dito frequentemente). Em um ensaio de catálogo, Dean Sobel descreve o procedimento de Demand do seguinte modo, começando com o produto final, a fotografia: "1 - Thomas Demand faz fotografias coloridas em grande escala. 2 - Suas fotografias são de maquetes de papel em escala real que ele mesmo produz. 3 - Essas maquetes são recriações de lugares reais. 4 - Ele se baseia em imagens que obtém de diversas fontes." ${ }^{6}$ Essa maneira de apresentar os projetos de Demand enfatiza seu telos fotográfico, mas isto precisa ser complementado por uma descrição que parta do começo para o final. "Como regra, Demand começa com uma imagem”, escreve Roxana Marcoci em um ensaio do catálogo da exposição no Museu de Arte Moderna de Nova Iorque em 2005, "geralmente, embora não exclusivamente, ele utiliza fotografias que seleciona na mídia, que ele traduz para um modelo tridimensional em tamanho real em papel. Então, ele faz uma fotografia da maquete com uma Sinar suíça, 
uma câmera de grande formato, com lentes telescópicas para uma melhor resolução e maior verossimilhança. O que contribui para aumentar a ilusão de realidade. Suas fotografias de grande formato são laminadas em plexiglas e expostas sem moldura... Então são imagens que estão triplamente distantes das cenas ou objetos que elas representam”.

Dentre os assuntos que Demand explora, um tipo recorrente tem sido descrito por vários comentadores como a cena de um crime (imprecisamente falando $)^{8}$. Por exemplo Room (1994) reencena uma fotografia do quartel de Hitler em Rastenburg, no leste da Prússia, depois de um atentado a bomba fracassado contra sua vida em 20 de julho de 1944; Corridor (1995), um de seus trabalhos mais conhecidos, é baseado no corredor do edifício em Milwaukee, onde o serial killer Jeffrey Dahmer viveu e cometeu assassinatos atrozes; Archive (1995) é uma alusão ao arquivo de filmes de Leni Riefenstahl, que fez Triumph of the Will, notório filme de propaganda do comício do partido Nazista em Nuremberg em 1934; Office (1995), com papéis espalhados por toda a cena, foi baseado em imagens dos escritórios da Stasi saqueados na sequência do colapso da Alemanha Oriental em 1989; Bathroom (Beaus Rivage) (1997), outra imagem bastante conhecida, reproduz uma fotografia de jornal de uma banheira num hotel de Genebra onde um proeminente político alemão foi encontrado morto sob circunstâncias misteriosas em 1987; Camping Table (1999) deriva de uma fotografia enviada pelos sequestradores de Jan Philipp Reemtsma em março de 1996 para mostrar que ele ainda estava vivo (a mesa de camping estava no fundo daquela fotografia $)^{9}$; Podium (2000) se refere ao discurso inflamado do líder sérvio Slobodan Milosovic realizado em 28 de junho de 1989 para o sexcentésimo aniversário da batalha de Kosovo; Model (2000) foi feita a partir de uma fotografia de Hitler e seu arquiteto favorito, Albert Speer, olhando para uma maquete do pavilhão alemão projetado por Speer para a exposição internacional em Paris em 1937; Pool (2001) representa o centro de Operações Emergenciais em West Palm Beach, Flórida, onde aconteceu a recontagem manual de 425 mil votos em 2000, na esperança de (legitimamente) determinar se $\mathrm{Al}$ Gore ou George W. Bush seria o presidente dos Estados Unidos ${ }^{10}$; e Kitchen (2004), que é baseada numa fotografia do esconderijo de Saddam Hussein no Iraque. Dois filmes curta-metragem também seguem esse padrão: Escalator (2000), em loop, composto por 24 imagens estáticas, evoca um local perto de Charing Cross em Londres por onde passaram

\section{Michael Fried}

Thomas Demand e suas alegorias da intenção; "exclusão" em Candida Höfer, Hiroshi Sugimoto, e Thomas Struth

7. $\mathrm{MARCOCl}$, Roxana. Paper moon. In: Thomas Demand, p. 9-10. Futuras referências a páginas desse ensaio estarão entre parêntesis no texto.

8. Ver, por exemplo, WIDMER, Ruedi. Interview with Thomas Demand: building the scene of the crime, Camera Austria International, n. 66, jul. 1999, p. 10. Na troca relevante, lê-se: Widmer: Vamos começar pelo começo. Para começar é um lugar cotidiano. Algo acontece..." Demand: "... e é algo que é tabu ou condenado na sociedade..." Widmer: “... um ato..." Demand: "...exatamente, um ato. E este ato é expulso do seu contexto cotidiano porque ele não pertence a ele. Porque ele produz algo que influencia a sociedade; porque ele está para além das fronteiras do desenrolar comum dos eventos." Widmer:

“Em seguida, vem alguém e tira uma fotografia." E na sequência (p. 11): Widmer: "O modo como você vê as coisas é referido, algumas vezes, como um 'detetive'. 0 que isso significa?" Para a resposta de Demand a essa pergunta, veja suas observações sobre Corridor,

9. Para um relato emocionante do sequestro e seus 33 dias de cativeiro, ver REEMTSMA, Jan Philipp. In the cellar. Trad. Carol Brown Janeway. Nova lorque, 1999. 
10. Sobel escreve: "Poll, como muitos dos trabalhos de Demand, tem a aparência de um rescaldo de uma cena de crime lque o local real talvez fosse, pois de acordo com alguns relatos de participantes, tais como os assessores dos candidatos e a Secretaria de Estado da Flórida, o jogo sujo pode ter tido um efeito na recontagem)". (Thomas Demand: The basic facts, $s / p$.$) .$

11. Mais recentemente, Demand expôs na Serpentine Gallery, em Londres no verão de 2006, cinco fotografias fazendo uma peça composta chamada Tavern (2006), baseada em "um evento ocorrido em um pequeno bar do lado oposto à estação de trem em Burbach, um distrito de Saarbrücken, onde um menino... foi sufocado com uma almofada e depois descartado em um saco de lixo. Sua irmã adotiva era a culpada." (DEMAND, Thomas. A conversation between Alexander Kluge e Thomas Demand. In: Thomas Demand. Londres, p. 85).
Paris onde a princesa Diana morreu. Outros lugares específicos reconstruídos e então fotografados incluem o quarto onde Bill Gates criou seu primeiro sistema operacional de computador (Corner, 1996); o quarto de hotel no qual L. Ron Hubbard, o fundador da Cientologia, escreveu Dianetics (Room, 1996); o escritório onde a reconstrução da cidade de Munique foi planejada após a segunda guerra mundial (Drafting Room, 1996); o celeiro em Long Island onde Hans Namuth fotografou Jackson Pollock produzindo uma de suas pinturas all-over drip em 1950 (Barn, 1997); e um quarto subterrâneo onde um mineiro austríaco ficou preso em escuridão total por quase dez dias antes de ser milagrosamente resgatado (Pit, 1999) ${ }^{11}$. E ainda, existem trabalhos baseados em motivos ligados mais ou menos diretamente à arquitetura, em maior ou menor grau - como por exemplo, Staircase (1995) - e fotografias que não se encaixam em nenhuma dessas categorias, como Studio (1997), que, para a audiência alemã, relembra um set de estúdio de um programa popular de TV alemão chamado Was bin ich? (Qual é minha fala? - uma pergunta que poderia ser feita pelo próprio Demand); Laboratory (2000), com a imagem de uma câmara acústica, usada na indústria motora para testar os níveis de ruído de máquinas; Collection (2001), baseado em fotografias da coleção dos discos de ouro do cantor Engelbert Humperdinck; e Space Simulator (2003), uma imagem de aproximadamente $3 \times 4$ metros do aparato usado para treinar astronautas norte-americanos. Finalmente, também há as fotografias de simulacros de grama feitos em papel (Lawn, 1998), e de densa folhagem atravessada por raios luminosos (Clearing, 2003).

Muitos pontos merecem ser enfatizados. $\mathrm{O}$ primeiro diz respeito à maneira como Demand escolhe as imagens - geralmente de jornais impressos, mídia impressa, ou da internet - e mais ainda, sua subsequente investigação das circunstâncias da produção dessas imagens. Como ele mesmo afirma na esclarecedora entrevista concedida a Ruedi Widmer:

Você deve ter uma ideia de onde a foto veio. Eu tento descobrir quem é o fotógrafo, o editor, como ela chegou à agência de fotos. E, frequentemente eu descubro imagens até mais interessantes neste processo. Por exemplo, para Corridor. Eu estava procurando fotos do interior do apartamento de Jeffrey Dahmer, o assassino em massa que foi espancado com uma vassoura 
até a morte dentro da prisão alguns anos atrás. Ele havia matado seis ou setes caras negros. Dahmer é um ídolo americano negativo. Eu vi uma foto de seu apartamento em um avião uma vez. Tentei encontrá-la de novo e por isso fui a Milwaukee. Todos me disseram que estas fotos do apartamento de Dahmer não existiam - do lugar onde ele tinha feito algumas de suas vítimas no chuveiro - porque a polícia não havia permitido a ninguém fotografar o lugar. Então eu fui ao lugar onde a casa estaria localizada. Mas desde que as evidências haviam sido colhidas, a casa foi derrubada, primeiro porque ninguém queria viver mais lá e, depois, porque um tipo de turismo, que a cidade queria evitar a qualquer custo, estava começando. Então esse lugar também não existe mais. Eu encontrei a foto depois, alguém a mostrou para mim. Embora ela não seja realmente interessante, eu vi centenas de fotos deste corredor e de fora da casa quando estava procurando as fotos. O corredor acabou se tornando a quintessência da banalidade que eu queria encontrar no apartamento e na foto, mas que não conseguia. (p. 11)

Um segundo ponto, ressaltado pela maioria dos comentadores, consiste nos dois estágios de resposta dos espectadores às suas fotografias - um primeiro estágio no qual a imagem parece fria e abstrata, e por outro lado ordinária, comum, e um segundo estágio no qual o observador sente que alguma coisa (de fato tudo) está "fora de lugar" ou errado, e progressivamente começa a reconhecer através de diferentes tipos de pistas, que o tema ostensivo da imagem nada mais é que uma reconstrução. De acordo com François Quinton:

Quando você olha para uma imagem de Demand, tudo parece uniforme, regular, mas os traços de sua fatura ainda podem ser vistos em algumas áreas. Cada detalhe chama a atenção: o que você vê não é a realidade do que é mostrado. Esta frágil construção de papéis recortados e dobrados revela suas imperfeições. "Eu não recorto o papel de propósito, para que você possa ver como ele foi cortado (disse Demand). Mas é verdade que a cada etapa eu posso escolher se deixo ou não visíveis estas pequenas falhas. Com o tempo, eu desenvolvi um sentido mais acurado deste tipo de sutileza. Esta, talvez, seja a perfeição a que meus esforços se dirigem." ${ }^{12}$

Na verdade, essa afirmação pouco admite o quão perspicaz é a estranheza ou a "desconexão" das imagens de Demand: você vê papéis espalhados sem nada escrito neles, caixas, garrafas e tubos sem logo-

\section{Michael Fried}

Thomas Demand e suas alegorias da intenção; "exclusão" em Candida Höfer, Hiroshi Sugimoto, e Thomas Struth

12. QUINTON, François. There is no innocent room. In: Thomas Demand, catálogo de exposição. Paris, 2000, p. 52. (Futuras referências a páginas dessa entrevista estarão entre parêntesis no textol. Como escreve Marcoci: "apesar de seu ilusionismo, os tableaux encenados de Demand revelam os mecanismos de sua feitura. Imperfeições mínimas - uma marca de lápis aqui, uma aresta exposta ali, um vinco no papel - são deliberadamente deixadas visíveis. A falta de detalhe e uma iluminação fria e uniforme, expõe o todo como uma construção. Uma vez que foram fotografados, os modelos são destruídos. As imagens resultantes são convincentemente reais e estranhamente artificiais."

(Paper Moon, p. 10).

13. DZIEWIOR, Yilmaz. A thousand words: Thomas Demand talks about "Poll". Artforum, vol. 39, maio 2001, p. 145. 
14. ADAMS, Parveen Demand without desire: the work of Thomas Demand.

Portfolio: contemporary photography in Britain, n. 38 , dez. 2003, p. 20. Ela também sugere que os objetos nas fotografias de Demand, porque evidentemente não são objetos de desejo, são 'objetos como eles são, ou pelo menos o mais próximo possivel deles que podem ser" (ibid., ligeiramente modificado no plural). Isto parece errado.

[0 jogo de palavras do título do artigo é impossível de ser traduzido para o português, pois é um trocadilho com a palavra demand nome do fotógrafo que, em inglês,

significa demanda, sendo a tradução literal 'demanda sem desejo'. N. do T.]

15. DURAND, Régis. Tracings. In: Thomas Demand. Paris, p. 87. há uma completa ausência de sinais de desgaste ou outras indicações de uso. (Isso sem falar na total ausência de pessoas). Como Demand pontua:

A produção das maquetes está no centro de um processo complexo. Meu trabalho foi realmente desenvolvido a partir da escultura. Os arredores que eu represento são para mim algo intocado, uma construção utópica. Nenhum rastro de uso é visível nas suas superfícies, e o tempo parece ter parado. Daqui surge um estado paradoxal de indeterminação, que, é claro, por um lado se opõe à ideia de instantaneidade (tão importante no início da fotografia) mas também se opõe à real natureza da escultura. $\mathrm{O}$ que poderia ser justificadamente chamado de um efeito deshistoricizador, está talvez relacionado à influência que a produção e distribuição digital de imagem na internet teve na nossa concepção de realidade. ${ }^{13}$

Outro fator que contribui para este efeito "deshistoricizador" é a recusa sistemática de Demand em dar mais do que títulos mínimos para suas fotografias. Como Widmer observa (seguindo a declaração de Demand citada anteriormente): "O aspecto criminoso de Corridor só pode ser apurado se você possui algum conhecimento acerca de quem foi Jeffrey Dahmer. Sem este conhecimento, temos apenas a "quintessência da banalidade" à qual você se referiu. A banalidade aparece quando a imagem é radicalmente destacada do mundo que representa. Um certo cheiro de corredor retorna como uma vingança apesar de você ter removido a maioria dos sinais". Ao que Demand responde: "Totalmente. Eu não estou essencialmente interessado no ato em si, mas mais na foto do ato como um tipo de imagem. Por isso é que minhas fotografias nunca têm nomes indicando de onde as coisas são. Primeiramente, eu apenas estou interessado no fato de que algo entrou em circulação em forma de fotografia. E aí, eu quero saber até que ponto você pode abstrair esta coisa sem que o trabalho perca sua autonomia...” (p. 11-14)

O terceiro ponto, uma vez que se tenha compreendido a construtividade de seus referentes, está relacionado às próprias fotografias produzidas, que são profundamente desconcertantes, o que eu acredito que seja o que Demand quis dizer com a referência à "indeterminação" - o que exatamente o observador faz com elas? (Mais sobre determi- 
nação versus indeterminação na sequência). Como diz Parveen Adams: "Confrontado com estes imperturbáveis e silenciosos escritórios, estes cômodos despovoados, as varandas cegas, e as garagens congeladas, eu não sabia mais para o que eu estava olhando. Nem convidativas nem sinistras, estas imagens não podiam ser incluídas no mundo."14 "O mundo de Demand é um mundo de papel” ela acrescenta, mas é claro que a questão é se se pode falar destas fotografias imaginando um mundo mesmo. Regis Durand caracteriza iluminadamente "a impressão paradoxal que os trabalhos de Demand nos causam” da seguinte maneira:

Como fotografias, elas capturam parte da energia de seu tema, sua presença indiferente, obstinada e misteriosa. Alguma coisa estava ali, e elas estão ligadas a essa coisa, seu nome, seu significado, sua história (e isso sem contar o fato de que o que temos à nossa frente é um truque visual, uma reconstrução), mas nada nestas imagens vibra; elas não suscitam em nós nenhuma projeção de desejo ou de presença. O espaço está inteiramente saturado, sem profundidade e sem nenhuma sugestão de que exista alguma coisa para além dali. Mais do que procurar referências da arte minimal aqui, nós precisamos entender que esta saturação, esta leve, porém sufocante, indiferença, é o coração das intenções do artista. Pois sob sua aparência formal variante, a tonalidade subjacente destes trabalhos permanece a mesma: existe a mesma saturação de temas a mesma luz não natural - uma luz que serve somente para dar sensação de volume aos objetos sem sugerir nenhuma profundidade de campo. ${ }^{15}$

Por "saturação" Durand se refere à qualidade que estas fotografias transmitem em não querer nada do observador, de não dar a ele ou ela nenhuma oportunidade de projeção empática de nenhum tipo, de fato elas contrariam qualquer possibilidade de imaginar alguma relação com as cenas representadas a não ser a de um olhar alienado.

O próprio Demand pensa sobre isso em termos de representação de um certo tipo de lugar. Ele disse a Widmer:

Eu me pergunto - Quais são os detalhes chave que devem ser incluídos [na maquete] para fazer de um lugar um lugar [Ort], em oposição a um lugar comum [Allgemeinplatz]. Eu não quero mostrar uma escrivaninha como tal, mas esta escrivaninha em particular que nós temos em nossa cabeça. $\mathrm{O}$ importante aqui é como a fotografia é feita. No banheiro (onde o político

\section{Michael Fried}

Thomas Demand e suas alegorias da intenção;

"exclusão" em Candida Höfer, Hiroshi Sugimoto, e

Thomas Struth

16. Ver KRAUSS, Rosalind E. Notes on the index: part I. The originality of the avant-garde and other modernist myths. Cambridge e Londres, 1985 , p. 203; ver também cap. 6 acima, n. 32. Os termos ícone e índice derivam dos escritos de Charles Sanders Pierce, a quem Krauss se refere em: Logic as semiotic: the theory of signs, In: Philosophic writings of Pierce. Nova lorque, 1955, p. 106. Mais recentemente, as visões de Krauss, juntamente com o seu uso de Pierce, foram criticados por Joel Snyder em Pointless. In: ELKINS, James (ed.). Photography Theory. Nova lorque e Londres, 2007, p. 369-400. Para Walter Benn Michaels em "Photographs and Fossils" (ibid., p. 432), no entanto, respondendo a Snyder e mais amplamente ao questionamento da noção de indicialidade como um marcador da fotografia em outros lugares do volume de

Elkins, “indicialidade - se somente na forma de um problema - é central tanto para a especificidade do meio da fotografia e, pelo menos nos últimos 20 anos, ao que Abigail Solomon-Godeau chama o outro tópico de interesse e controvérsia neste volume, 'a relação da fotografia com o discurso histórico da arte'." Michaels acrescenta em uma nota: "A indicialidade é [central para a especificidade do meio da fotografia, etc.], mas Pierce provavelmente não é. Nós devemos desconectar a reivindicação de que a conexão causal distintiva entre 

sensação de segurança. Um sentimento de que ele não tem nada a ver com isso... (p. 11)

o referente de uma fotografia e a fotografia mesma é importante para a teoria da fotografia da reivindicação de que a semiótica de Pierce é igualmente importante. A última reivindicação pode ser verdade mas não é consequência da primeira" (p. 448). Eu terei mais a dizer sobre o ensaio de Michaels na conclusão deste livro.

17. Ver FRIED, Michael, Art and objecthood (1967). In:

Art and objecthood: essays and reviews. Chicago e Londres, 1998, p. 148-172.

(Futuras referências a páginas deste ensaio estarão entre parêntesis no texto.) Ver também idem, Shape as

form: Frank Stella's eccentric polygons (1966), p. 77-99, e An introduction to my art criticism, p. 40-47.

18. Ver MORRIS, Robert. Notes on sculpture, part 2. In:

Continuous project altered daily: the writings of Robert Morris. Cambridge e Londres, 1993, p. 15. 0 ensaio de Morris apareceu originalmente em Artforum, vol. 5, out. 1966, p. 20-23.

19. Art and objecthood, op. cit., p. 153. Walter Benn Michaels comenta sobre essa declaração como segue: "0 'virtualmente' aqui é um pouco enganador porque, como Fried continua dizendo, embora o 'objeto, não o espectador, precisa permanecer no centro ou foco da situação', 'a situação mesmo pertence ao espectador - é a sua situação'.
Mas é claro, que essa "sensação de segurança" ou o "sentimento de que ele não tem nada a ver com isso" é precisamente a forma de deixar o observador de fora da imagem emocionalmente e imaginativamente - de "excluir" ele ou ela, para usar o termo que introduzi a propósito do Tableaux de Bustamante no capítulo 1. Aqui cito mais um excerto entre Demand e Widmer:

RW: Então, o que tem a ver a reconstrução de lugares com reviver eventos? TD: O curioso é que uma vez terminado o lugar e ao se deparar com ele na sua frente, surpreendentemente, em tamanho natural, é possível adentrar ali como numa simulação digital. Você na verdade não existe como você mesmo. Esta sensação de eternidade e virgindade, um sentimento de que tudo é novo e não foi usado, acomete o espectador que circula neste tipo de espaço.

RW: Isto tem a ver com o fato de que a reconstrução - assim como o isolamento de uma cena do crime - na verdade extrai o espaço dos acontecimentos do espaço da percepção.

TD: Ou se poderia dizer: a subsequente presença do espectador é absolutamente exclusiva. Não há um lado de fora, não existe uma esfera pública, não existem outras pessoas ali. Existe somente a pessoa per se. Mas a coisa engraçada é que se pode utilizar muito da sua experiência de vida. A única coisa é que o contexto em que estas experiências foram adquiridas desapareceu completamente. (p. 15)

Demand parece estar se referindo (pelo menos no início) somente às maquetes, mas suas observações também se aplicam às fotografias que faz delas, admitindo que o observador não se movimenta de fato por dentro desses lugares construídos. Como ele mesmo diz sobre seu projeto como um todo, "eu estou no mesmo mundo midiático que você, e me dei conta de que existem lugares que todos conhecemos mas que nunca colocamos os pés. E eu sinto que é melhor ficar nesses lugares e reinterpretá-los do que inventar novas coisas. Como um tipo de privatização do mundo público das imagens ao invés de simplesmente seguir 
criando mais e mais novas imagens que irão competir entre si...” (p. 14)

De maneira levemente diferente, o projeto de Demand - conforme já reconhecido por vários escritores - indica uma reinvenção do elo tradicional entre fotografia e indicialidade. "Toda fotografia é o resultado de uma impressão física transferida por reflexos de luz sobre uma superfície sensível”, escreveu Rosalind Krauss no ensaio chave dos anos 1970 "Notes on the index". "A fotografia é então um tipo de ícone, ou semelhança visual, que sustenta uma relação indicial com seu objeto"16 (Como foi observado de passagem, a noção de que fotografias são indiciais é crucial à argumentação de Barthes em A câmara clara. Esse tópico voltará na conclusão deste livro.) Agora, de maneira óbvia, isto também é verdade para as fotografias de Demand: elas sustentam uma relação indicial com as maquetes de papel feitas por Demand, cuidadosamente iluminadas e fotografadas. Ainda que as maquetes sejam diferentes dos seus originais, suas fontes do mundo real (quer dizer, pré-mediatizadas), em virtude de terem sido construídas em papel, e também porque os termos dessa reconstrução são, em aspectos cruciais, radicalmente incompletos, as imagens estão isentas de qualquer traço de indicialidade de suas fontes e de seus contextos - toda marca de uso, todo vestígio da presença humana ou sua ação, o que também significa a mínima sugestão de um passado, de historicidade, do "isso-foi" no qual Barthes viu o noema da fotografia. (Demand: "Nenhum rastro de uso é visível nas suas superfícies, e o tempo parece ter parado.") Colocando isto por um prisma levemente diferente, as fotografias de Demand representam lugares e coisas absolutamente desprovidas, na verdade purgadas sistematicamente, de qualquer traço que não sejam os que pertencem à construção física das maquetes de papelão daqueles lugares e suas coisas, produzidas pelo artista. Tal objetivo se torna mais saliente (e ainda mais intrigante) pela escolha repetida de cenas de crimes ou outros eventos notáveis, cenas que na sua manifestação original (ou conforme foram fotografadas originalmente) inevitavelmente guardam traços da história destes eventos sobre suas superfícies. Por isso mesmo é que a polícia alemã estudou de perto a fotografia do Reemstma quando sequestrado, atrás de pistas sobre seu paradeiro. Por isso também, que caçadores de curiosidades em Milwaukee seguiam visitando o prédio de apartamentos no qual Dahmer viveu, o que provocou a decisão da construtora de derrubar o edifício, para evitar este tipo de turismo.

\section{Michael Fried}

Thomas Demand e suas alegorias da intenção; "exclusão" em Candida Höfer, Hiroshi Sugimoto, e Thomas Struth

A presença do espectador é estrutural mais que empírica, desde que sem ele não há situação e portanto não há arte literalista. 0 ponto aqui não é um tipo de idealismo geral, não a ideia de que o objeto vem à existência somente quando o espectador o encontra e portanto que há algum sentido em que ele o cria. Embora esta posição vá rapidamente emergir como central para certas formas de teoria literária, na descrição de Fried do Minimalismo, o objeto existe por conta própria bem; o que depende do espectador é somente a experiência. Mas, é claro, a experiência é tudo - é a experiência no lugar do objeto que o Minimalismo valoriza" (The shape of the signifier: 1967 to the end of history. Princeton e Oxford, 2004, p. 89). 0 livro de Michaels é uma crítica ampla de textos teóricos e ficcionais recentes, os quais cometem todos o erro de "pensar a literatura [ou a arte] nos termos da experiência do leitor [ou espectador] mais que nos da intenção do autor, e [de substituir] a questão de quem são as pessoas pela questão do que elas acreditam" (da capa do livro).

20. Provavelmente isso se torna quase explícito em certas observações sobre o trabalho do escultor britânico Anthony Caro. Por exemplo: "Uma escultura característica de Caro consiste, eu quero dizer, na justaposição mútua e nua das vigas em I, traves, cilindros, extensões de canos, folhas de metal, e grades que 
A questão, está claro, é porque Demand escolheu estes procedi-

ano 14

ก. 28

ela compreende mais do que o objeto composto que eles compõem. A inflexão mútua de um elemento no outro... é o que é crucial... Os elementos individuais conferem significância um ao outro precisamente pela virtude de sua justaposição: é nesse sentido, um sentido inextricavelmente envolvido com o conceito de significado, que tudo o que na arte de Caro

vale a pena olhar está em sua sintaxe [primeiramente dito por mim na minha introdução à exposição de Caro de 1963 na Whitechapel]...

É como se as esculturas de Caro essencializassem a significância como tal como se a possibilidade do significado do que dizemos e fazemos sozinho fizessem sua escultura possível. Tudo isso, é quase desnecessário acrescentar, torna a arte de Caro um guia da sensibilidade antiliteralista e antiteatral" (Art and objecthood, p. 161-162).

21. De "Art and objecthood": "o espectador [de um trabalho minimalista/literalista] sabe que ele permanece em uma relação indeterminada, aberta

- e inexata - como sujeito para o objeto impassível na parede ou no chão" (p. 155). A antítese entre a determinação modernista e a indeterminação minimalista/literalista (e também do pós-modernismol é um tema central em Jennifer Ashton (From Modernism to

Postmodernism. American poetry and theory in the Twentieth Century (Cambridge e Nova lorque, 2005). mentos - qual o objetivo artístico e intelectual de tanto trabalho e, em aspectos óbvios, de tanto esforço bizarro? Insistir na importância do ponto de que Demand iniciou sua carreira artística como escultor não responde satisfatoriamente a questão: porque essa ambição escultórica o levou a reconstruir lugares e coisas já existentes, e porque ainda fotografar essas reconstruções? A meu ver, também não respondem declarações como as feitas por Marcoci: "Bathroom de Demand aponta para evasões e para a falha da fotografia em ajudar a entender a violência que existe atrás da aparente ambiguidade da vida política." (p. 22) Ou seu argumento final de que "Demand garante que a fotografia se torne um veículo de consciência tanto quanto um testemunho para se ver de uma nova maneira” (p. 27). (Há muito desse tipo de argumento na crítica sobre Demand.) Eu proponho uma leitura diferente do que Demand vem fazendo nos últimos quinze anos.

Em "Art and objecthood" e em ensaios relacionados, eu propus uma distinção precisa entre a pintura e a escultura modernistas e os trabalhos e escritos dos minimalistas, ou como eu costumo chamá-los, literalistas - Donald Judd, Robert Morris, Carl Andre, e Tony Smith, entre outros ${ }^{17}$. Para os literalistas, o que importava ou deveria importar naquele momento, não eram as relações internas do trabalho de arte, como acontecia no auge das pinturas e esculturas modernistas, mas a relação entre o trabalho de arte literalista e o sujeito da experiência, como o último era convidado a ativar (e de fato a produzir) essa relação no decorrer do tempo, ao entrar no espaço da exposição, ao se aproximar ou afastar-se, ou ao circundar o ostensivo trabalho (ou, como no caso das peças de chão de Carl Andre, andando sobre o trabalho), e com isso ir comparando as mudanças de percepção do trabalho e também ter a compreensão intelectual da sua forma básica, e assim por diante. Citando Morris (como fiz em "Art and objecthood"):

Os melhores novos trabalhos levam a relação para fora do trabalho de arte, e fazem dela uma função do espaço, da luz e do campo de visão do observador. O objeto é apenas mais um dos elementos desta nova estética. De alguma forma isto é mais reflexivo, porque a consciência de existir no mesmo espaço que o trabalho é mais forte do que nos trabalhos anteriores, com suas muitas relações internas. O sujeito se torna mais consciente do que antes, já que ele próprio está estabelecendo relações a partir da percepção dos objetos das vá- 
rias posições e sob condições variadas de luz e de contexto espacial. (p. 153) ${ }^{18}$

$\mathrm{O}$ que interessava, em outras palavras, era a experiência real e em tempo real do sujeito com o trabalho, ou ainda a situação total em que o trabalho era encontrado, uma situação que, como eu disse em "Art and objecthood", "virtualmente por definição, inclui o espectador"19 - o que também quer dizer que se referir à relação em questão como estando "entre" o trabalho e o espectador não captura exatamente a ideia literalista (nem "espectador" se encaixa aqui exatamente). O trabalho literalista, em outras palavras, fica por definição incompleto na ausência do sujeito que o experiencia, que é o que eu quis dizer ao caracterizar esse tipo de trabalho de teatral, no sentido pejorativo do termo. As pinturas e esculturas do alto modernismo, em contraste, considerei fundamentalmente antiteatrais porque (para usar uma metáfora) elas nem se dão conta do espectador, que deve por si chegar a um acordo com elas - para produzir sentido a partir das relações que elas compreendiam - da melhor maneira que pudesse. (Que, das pinturas do alto modernismo, como as "Unfurleds" de Morris Louis, poderia se dizer que elas enfrentam o espectador com extraordinária franqueza, o que torna sua estrutural indiferença à sua presença real diante delas ainda mais perspicaz.) Um outro contraste ainda, que em "Art and objecthood" permanece amplamente implícito, se refere ao fato de que enquanto nas pinturas e esculturas modernistas as relações constituintes eram intencionadas pelo $\operatorname{artista}^{20}$, as relações entre as obras literalistas e o sujeito que as experiencia, apesar de condicionadas de uma maneira geral pelo contexto da exposição, eram entendidas pelos literalistas como enfaticamente não determinadas pelo próprio trabalho, e portanto, não eram intencionadas como tais pelo seu produtor. Ao contrário, a primazia da experiência no sentido estabelecido acima significa que o sentido no literalismo era essencialmente indeterminado, toda resposta necessariamente única em tempo real do sujeito a um dado trabalho-em-uma-situação estava em pé de igualdade com qualquer outro. $^{21}$

Olhando por esse contexto, o significado do projeto de Demand fica claro. Simplesmente colocado, ele pretende substituir a cena original com vestígios de provas e marcas de uso - ou ainda ele pretende substituir uma ou mais imagens midiáticas de uma determinada cena - com uma contra-imagem de intenção puramente artística, como se a própria bizarrice do fato dos lugares e objetos nas fotografias, apesar de

\section{Michael Fried}

Thomas Demand e suas alegorias da intenção; "exclusão" em Candida Höfer, Hiroshi Sugimoto, e

Thomas Struth

22. *N. do T. Pace: preposição do sec. XIX do latim pāx que quer dizer: com a devida deferência para. Usado para acusar educadamente alguém que não concorda com o falante ou escritor.

23. A Conversation between Alexander Kluge and Thomas Demand, p. 56 .

24. Ver BERGER, John e MOHR, Jean. Another way

of telling. Nova lorque, 1982, p. 90. Nas frases anteriores lê-se: "0 fotógrafo profissional tenta, ao tirar uma fotografia, escolher um instante que vai persuadir o público observador a emprestar a ele um passado e um futuro apropriado. A inteligência do fotógrafo ou sua empatia com o assunto define para ele o que é apropriado.

Mas, diferentemente do contador de estórias ou do pintor ou do ator, o fotógrafo faz somente, em qualquer fotografia, uma única escolha constitutiva: a escolha do instante a ser fotografado. A fotografia, comparada a outros meios de comunicação, é, portanto, fraca em intencionalidade" (p. 89-90). 0 leitor vai sentir provavelmente, justificadamente em minha visão, que um fotógrafo faz muito mais que apenas uma escolha constitutiva no ato de tirar uma fotografia: ele ou ela seleciona um assunto, escolhe a distância e o ponto de vista, faz ajustes para a iluminação, com frequência modifica a velocidade ou a abertura do diafragma, etc. (Na verdade, nós provavelmente 
sua aparência inicial de "realidade" cotidiana, terem sido todos constru-

ano 14

ก. 28

deveríamos iniciar muito antes, com a seleção da câmera e do filme.) Ainda assim, a tese básica de Berger, de que há algo na natureza da fotografia que escapa a total determinação do fotógrafo, pode, contudo, ser mantida. A observação de Berger é citada e discutida por MICHAELS, Walter Benn. Action and accident: photography and writing. In: The gold standard and the logic of Naturalism. Berkeley, Los Angeles e Londres, 1987, p. 236-238. Ver também o ensaio de Michaels, Photographs and Fossils em Photography theory, e as páginas sobre fotografia (sobretudo sobre o trabalho de James Welling) em The shape of the signifier, p. 95-105.

25. MICHAELS, Walter Benn. Action and accident, op. cit., p. 230. A frase ocorre em uma sentença que lida com a questão se Lily Bart, em

The House of Mirth, de Edith Wharton, quis ou não se matar quando tomou uma overdose fatal de chloral. "Parece equivocado, no entanto, dizer tanto que ela quis quanto que ela não quis," escreve Michaels, "pois todo impulso do romance é insistir em um econômico, erótico, e moral encanto das ações que é marcado por uma discrepância irredutível entre intenção e efeito." O ponto de Michaels é que a mesma discrepância é básica para o discurso mais ou menos contemporâneo da fotografia. Cf. Observações de Diane Arbus, citadas e discutidas no capítulo 7: ídos pelo artista trazem um alívio conceitual para a força determinante - mesmo sua inescrutabilidade, ou poderia se dizer sua opacidade - nas intenções por detrás delas. Isto é o que a noção de "saturação" proposta por Durand significa: as fotografias de Demand estão "saturadas" com as suas intenções, por isso é que elas não deixam espaço para mais nada, é por isso que o observador reconhece instintivamente que a imagem requer dele e dela nada mais do que reconhecer a "feitura" de todos aqueles objetos à vista e do lugar onde eles existem. A noção de "saturação" também nos ajuda a entender porque é crucial que os trabalhos em questão sejam fotografias e não simplesmente as próprias maquetes (pace $^{* 22}$ : Demand afirma para Widmer ser possível entrar em suas maquetes como uma "simulação de computador"). Como coisas no mundo, que ocupam o espaço real, tridimensional, as maquetes de Demand não seriam mais "saturadas" com suas intenções que qualquer outra coisa feita (artística ou não) é com as intenções de seu produtor ou produtores, o que também quer dizer que estariam no mesmo nível, ontologicamente falando, que um contexto mais amplo do mundo real (o ateliê do artista, por exemplo, ou uma galeria de arte ou museu) no qual fossem encontrados. Enquanto que ao fotografar os objetos e os lugares que constrói (e nada além disso), Demand efetivamente substitui o contexto do mundo real por um meramente representado, cada detalhe ou aspecto do qual é exatamente o que ele quer que seja. Assim, por exemplo, a determinação na e pela fotografia de um ponto de vista particular está em contraste gritante com a relativa indeterminação neste mesmo sentido da maquete tridimensional considerada por ela mesma. Como Demand observa para Alexander Kluge: "Você pode andar em torno de uma escultura quanto quiser, já com a fotografia - as minhas são muito grandes então, assim como com as esculturas, você pode andar em volta delas - você tem um [singular, para sempre fixo] momento e meu ponto de vista particular. Minha condição tirânica, por assim dizer, é que eu determino a sua visão" ${ }^{23}$. De volta a Baudelaire, sobre a superioridade da pintura em relação à escultura, citado por Chevrier no capítulo 6: "'Uma pintura... é somente o que ela quer ser; não há maneira de olhar para isso, a não ser nos seus próprios termos. Pintura tem apenas um ponto de vista; e este é exclusivo e absoluto.” O ponto de Chevrier em relação à visão de Baudelaire em 1846 sobre a escultura antecipa minha crítica em "Art and objecthood" da objetidade minimalista/literalista; 
e espantosamente, também antecipa a prática fotográfica de Demand.

Uma outra dimensão do trabalho de Demand emerge quando se recorda que a fotografia como meio tem sido tratada tradicionalmente como "fraca em intencionalidade", de acordo com John Berger. ${ }^{24}$ Mais precisamente, há muito se reconhece que no fazer da fotografia tem uma "discrepância irredutível entre intenção e efeito" ${ }^{25}$, ou de maneira mais simples, que um fotógrafo não sabe exatamente o que fez até que a fotografia esteja pronta (revelada e ampliada). Como afirma a famosa frase de Winogrand: "Eu fotografo para descobrir como algo vai parecer quando fotografado". ${ }^{26}$ Ao que Friedlander famosamente acrescentou: "Eu só queria meu tio Vern em frente ao seu novo carro (um Hudson) num dia claro. Eu tenho ele e o carro. Eu também tenho um pouco a lavanderia da tia Mary e Beau Jack, o cachorro, urinando numa cerca, e uma fileira de vasos de begônias na varanda, e setenta e oito árvores e um milhão de seixos à beira da estrada e mais. A fotografia é um meio generoso." ${ }^{27}$ Como a observação de Friedlander sugere, a "fraqueza em intencionalidade" de Berger é correlativa à abundância extraordinária incorporada à tecnologia (o fotógrafo sempre consegue mais do que pede), uma característica do meio que tem sido o gênio de certos fotógrafos, Friedlander entre eles, explorada ao máximo. (Assim, o que quer que "fraca em intencionalidade" queira significar, ela não impede que a fotografia tenha sido o veículo de fortes e imaginativas intenções por parte de fotógrafos talentosos. Ao mesmo tempo, é precisamente esta característica da ontologia da fotografia que sublinha a noção de punctum de Barthes). Ao final do século XIX e início do século XX o componente mecânico da fotografia foi considerado por alguns teóricos, incluindo importantes praticantes, como motivo de um problema difícil para a fotografia ser considerada como arte, já que uma obra de arte deve ser, em cada detalhe, determinada pelas intenções do artista. ${ }^{28}$ Ao longo do tempo, isso deixou de ser uma questão ${ }^{29}$, em grande medida porque gerações de artistas fotógrafos, desde meados do século XIX, passaram progressivamente a ser vistos como tendo produzido fotografias com alto grau de individualidade, e claro com o advento da do digital, foi possível fazer imagens fotográficas que pretendem ser vistas como completamente intencionais tanto como representação quanto como artefato, eliminando, portanto, toda a "fraqueza" no sentido dado por Berger. Gursky e Ruff são figuras bem conhecidas que, mais do que outros, exemplificam este desenvolvimento, mas ele tornou-se genera-

\section{Michael Fried}

Thomas Demand e suas alegorias da intenção;

"exclusão" em Candida Höfer, Hiroshi Sugimoto, e

Thomas Struth

"Todo mundo tem aquela coisa em que eles precisam ter uma determinada aparência mas eles se apresentam com outra e é isso que as pessoas observam... Todo nosso aspecto é como dar um sinal para o mundo pensar em nós de uma certa forma, mas há um ponto entre o que você quer que as pessoas saibam de você e o que você não consegue evitar que as pessoas saibam sobre você. $E$ isso tem a ver com o que eu sempre chamei a lacuna entre intenção e efeito"

(Diane Arbus: an aperture monograph. Nova lorque,

26. Citado em LONGWELL, Dennis (ed.). Monkeys make the problem more difficult: a collective interview with Gary Winogrand. Image, vol. XV, n. 2, jul. 1972, p. 4.

27. FRIEDLANDER, Lee. An excess of fact. In: The desert seen. Nova lorque, 1996, p. 104. Citado por Galassi, Peter. You have to change to say the same. In: Friedlander, catálogo de exposição. Nova lorque, 2005, p. 14.

28. Ver MICHAELS, Walter Benn. Action and accident, op. cit., especialmente p. 217-220.

29. Uma simplificação exagerada, no sentido em que uma versão dessa ideia sobreviveu (ou retornou) em uma forma invertida na valorização do pósmodernismo da fotografia, que positivamente visava não ser arte. 
ano 14

ก. 28

"Portanto", Michaels escreve, "em um ensaio importante chamado 'Photography after art photography', Abigail Solomon-Godeau podia argumentar que a

fotografia veio 'figurar como um termo crucial no pósmodernismo' precisamente enquanto ela repudiava a ambição de transformar fotografias em trabalhos de arte e havia tomado uma aproximação instrumental ao meio', como nas Untitled film stills, de Cindy Sherman, compreendidas apenas como registros fotográficos dos disfarces e poses da artista" (The shape of the signifier, op. cit.,, p. 97-98). Michaels continua reabilitando as reivindicações da fotografia de arte, grandemente nos termos de uma discussão do trabalho de James Welling. 0 leitor vai se lembrar que no capítulo 1 eu sugeri que o relato pós-modernista do papel da fotografia nas Untitled film stills de Sherman pode bem tê-las vendido como arte neste sentido.

30. *N. do T. Hanging chads é o termo utilizado para se referir a um tipo de falha que ocorreu no procedimento de votação nos Estados Unidos da América no ano 2000 em que as cédulas eram perfuradas para marcar a escolha do eleitor e, neste caso, a falha se refere ao fato de que em algumas dessas cédulas, as perfurações ficaram incompletas e os cantos das cédulas não foram devidamente destacados. na fotografia de arte nos anos seguintes.

As fotografias de Demand, contudo, não são digitais - o efeito derradeiro de seu trabalho depende da convicção de quem olha, uma vez que ele ou ela tenha tempo para refletir, que a fotografia é a representação direta de configurações e objetos que realmente existiram e que na verdade foram meticulosamente fabricados pelo artista. Somente se a fotografia for vista como direta (quer dizer, indicial) a aparente feitura dos lugares e objetos pode ser tomada como factual pelo observador. Para retomar um aspecto já discutido num novo contexto, o objetivo de Demand não é fazer um objeto completamente cheio de intencionalidade - neste caso, uma fotografia totalmente digital- mas ao invés disso produzir imagens que representam ou de fato alegorizam a pretensão como tal, e isto acaba por explorar a "fraqueza" da imagem fotográfica tradicional precisamente a esse respeito. Uma intuição desse tipo, eu suspeito, foi o que levou Demand a fotografar suas maquetes escultóricas em primeiro lugar, e esse também foi o motivo de, na entrevista com Quinton citada anteriormente, ele ter sido levado a dizer, "Neste momento [uma vez tirada a fotografia], a escultura não é mais tão importante, mas também não o é a fotografia... Eu nunca pensei no meu trabalho como culminando na fotografia pura" (p. 46). O que é importante para Demand é um projeto ontológico altamente específico, no qual o fazer das fotografias leva a um termo. Visto por esse prisma, Poll é particularmente exemplar desse projeto no sentido em que o que ocorreu no Centro de Operações de Emergência era ostensivamente uma tentativa das autoridades da eleição, que durou dias, de determinar as intenções de um número substancial de eleitores da Flórida pelo meticuloso estudo das cédulas de votação que supostamente carregavam os traços daquelas intenções ainda que de forma dúbia (o notório "hanging chads" ${ }^{30}$ e assemelhados). Na fotografia de Demand, contudo, as cédulas não somente estavam imaculadas como desprovidas de texto, o que significa dizer que - assim como os telefones, lanternas, folders, post-its, e as superfícies das mesas nas quais tudo isto estava posto e sem espaço para pessoas sentarem ou estarem em pé - são manifestamente os portadores de nada além das intenções do próprio artista.

Para ir mais além, isso revela que as intenções em questão devem ser completamente conscientes. E isso se torna claro com as circunstâncias em torno do fazer de outro trabalho diferentemente exemplar, 
Sink (1997), que se originou de um impulso de Demand de reconstruir sua própria pia cheia de louça suja. "Minha intenção", disse a Quinton, "era fazer um trabalho extremamente simples - nada espetacular, isento de qualquer narrativa. No dia em que resolvi fazer esta peça, logo percebi que, sem querer, eu estava fazendo uma verdadeira composição na minha pia. Eu caí na minha própria armadilha. Quando eu entendi que eu nunca conseguiria fazer uma pia que fosse inocente o suficiente, eu liguei para um amigo e lhe disse 'você pode ir até sua pia e fotografá-la para mim?' Eu queria que ela fosse suficientemente isenta de significação para criar um equilíbrio. Sink é um precioso contraponto para meus outros trabalhos" (p. 56). Demand nunca poderia fazer uma pia suficientemente inocente porque ele nunca poderia descartar a possibilidade de que as intenções inconscientes o conduziriam a fazer uma "composição" em sua pia não importando o quanto ele conscientemente tivesse intenção de não fazer. Construir uma maquete de sua própria pia poderia, portanto, produzir no máximo um resultado "misto", enquanto que reconstruir e então representar no seu procedimento usual a pia de outra pessoa, significava que todas as intenções que importam na imagem final estavam sob o seu controle. Isso não significa negar que fatores inconscientes poderiam a princípio ter influenciado a escolha de seu tema, a fatura da maquete, e talvez até a iluminação da cena e a determinação do ponto de vista. Talvez até mesmo a escolha do amigo! E claro que incontáveis intenções além das dele próprio, já estavam presentes em seus equipamentos mesmo antes do início. Contudo ao rejeitar sua própria pia em favor da pia do amigo, coloca a ênfase nos processos conscientes. A pequena fotografia resultante, uma vitória colorística, é memorável pelo jogo quase espectral dos reflexos do aço inoxidável das paredes internas da pia, ou ainda pela integração destes reflexos na brilhante geografia aparentemente improvisada da imagem como um todo ${ }^{31}$.

Outras fotografias de Demand também possuem esse caráter exemplar, o que sugere que o termo talvez sirva para sua obra como um todo mais do que para instantes particulares dentro dela (a noção de intencionalidade alegorizante insinua muito). Por exemplo, Collection alude à exibição dos discos de ouro do cantor Engelbert Humperdinck, discos de vinil que não são nada mais do que impressões físicas de sons gravadas no acrílico em alguma ocasião passada; os discos reconstruídos na imagem são, portanto, para serem vistos como substituindo aquelas impressões com ao menos a sugestão de ranhuras feitas somen-

\section{Michael Fried}

Thomas Demand e suas alegorias da intenção; "exclusão" em Candida Höfer, Hiroshi Sugimoto, e

Thomas Struth

31. Estudos importantes sobre o assunto da não composição na arte do século $X X$ inclui: BOIS, Yve-Alain. Strzeminski and Kobro: in search of motivation. In: Painting as model. Cambridge e Londres, 1990, p. 123-155; idem, Surprise and equanimity. In:, Robert Ryman, catálogo de exposição. Nova lorque, 1990 , s/p.; idem, The limit of almost. In: Ad Reinhardt, catálogo de exposição. Nova lorque, 1991, p. 11-33; idem, Ellsworth Kelly in France: anti-composition in its many guises. In: Ellsworth Kelly: the French years, catálogo de exposição. Washington, D.C., 1992, p. 9-36; e SINGERMAN, Howard. Noncomposition effects, or the process of painting in 1970. Oxford Art Journal, vol. 26, 2003, p. 125-150.

32. N. do T. Câmara anecóica é uma sala projetada para conter reflexos, tanto de ondas sonoras quanto eletromagnéticas.

33. Em primeiro lugar por ele, ou com sua aceitação: Unconscious places era o título da sua exposição de paisagens urbanas em preto e branco que abriu em Berna em 1987 antes de viajar para Portikus, Frankfurt-am-Main, and Münster; o catálogo continha ensaios de Ulrich Loock, Ingo Hartmann, e Friedrich Meschede. Ver também LOOCK, Ulrich. Thomas Struth: "Unconscious Places". In: Parkett, n. 23, primavera de 1990, p. 28-31. 
ano 14

ก. 28

34. Cf. HAMBOURG, Maria Morris e EKLUND, Douglas. The space of history. In:

Thomas Struth 1977-2002, catálogo de exposição. Dallas, Los Angeles, Nova lorque, Chicago, 2002: "As paisagens urbanas de Struth apresentam o presente com seu impacto passado, em que cada momento dado é apenas o acúmulo de intenções passadas que podem ser desvendadas pela fotografia. Como parentes posando para uma fotografia de grupo, cada estrutura na rua parece possuída da mesma mistura paradoxal de autonomia e interdependência. Em uma piazza romana, um (uma estátua de um) bispo intercede em favor de um carrinho instável sobre as linhas evanescentes de um estacionamento... Outros lugares, como a nova praça em Dortmund, Alemanha, exalam uma sensação de estranheza e mal-estar cívico, uma soma total de más escolhas desde a banal arquitetura do parque temático 'alemão' até a fachada do shopping center e o desconfortável trio de ciprestes deslocadas" (p. 161-

162). Em última instância, eles acreditam que as paisagens urbanas de Struth são terapêuticas em intenção: os indivíduos podem reestruturar seus ambientes, e suas fotos

“sensibilizar-nos para o nosso entorno, encorajando-nos a escutar melodias particulares de tudo o que é germânico"

(p. 162). anecóica $^{32}$, um dispositivo desenhado para suprimir qualquer eco, o que quer dizer que elimina qualquer traço de sons prévios, no sentido de ativar uma absoluta presentidade do som que - sem dúvida, de maneira não intencional por Demand - relembra o assunto da presentidade em "Art and objecthood": como se precisamente esta característica da câmara fizesse de uma imagem dela uma fonte ideal para o próprio projeto de Demand de eliminação do traço e, se eu estiver certo, que é implicitamente antiliteralista. De maneira mais simples, Clearing, uma grande fotografia de uma massa de folhagem atravessada por um feixe de luz, permite o reconhecimento pelo espectador de que o formato e a posição de cada folha de papel foi, no final, determinada não pelo DNA das árvores e plantas de verdade (em conjunção com os fatores locais como solo, luz, etc.) mas pela ação deliberada do artista (neste caso, ajudado também por seus assistentes), assim como Constellation (2000), uma imagem do céu da Suíça exatamente trezentos anos depois da data de abertura de uma exposição dos trabalhos de Demand em Zurique, envolve a substituição de uma forma similarmente objetiva de causalidade pelas intenções do artista; e assim vai.

Finalmente, será útil comparar brevemente o projeto ontologicamente excepcional de Demand com aquele de Thomas Struth das suas primeiras fotografias em preto e branco, de tamanho modesto, excepcionalmente detalhadas, das ruas de Nova Iorque, Düsseldorf, e outras cidades europeias, a maioria das quais apresentavam composições centralizadas baseadas em um ponto de perspectiva. (As fotografias de Struth também têm a ver com as fotografias de interior de Candida Höfer, que logo serão consideradas). Quase a partir do princípio, as paisagens urbanas de Struth foram colocadas sob a rubrica de "lugares inconscientes"33, pelo qual o que parece que se queria dizer é que as cenas urbanas que elas representam foram imaginadas exercendo uma influência inconsciente em seus habitantes - quem, contudo, está por sua vez ausente da fotografia. Outra característica importante destes trabalhos (outro aspecto de sua ressonância "inconsciente") é que muito frequentemente eles mostram lugares ou redondezas, aos quais o espectador é convidado a entender, que chegaram a sua forma atual através do exercício, no decorrer do tempo, das intenções e decisões de arquitetos, desenvolvimentistas, e simples construtores, assim como de ações ao longo do tempo, para o bem e para o mal, não somente dos habitantes daqueles lugares mas 
também, por assim dizer, das forças sociais e econômicas que modelaram os bairros em questão, mas que mesmo assim transmitem a impressão de que cada lugar ou redondeza como um todo nunca teve a intenção de ser exatamente o que atinge o espectador da fotografia. De uma forma ligeiramente diferente, os lugares nas fotografias de Struth tipicamente representam a colagem de traços de múltiplas intenções, traços feitos em momentos diferentes, mesmo muito distantes, desse modo modificando, cobrindo ou apagando os traços de intenções prévias, de tal modo que a cena como um todo apresenta-se como carimbada em todos os lugares por intenções, embora (com algumas exceções) não por uma intenção individual ou coletiva para produzir a cena, o lugar, a redondeza como ela aparece ao observador ${ }^{34}$. Até mesmo nessas fotografias - Hörder Brïckenstrasse, Dortmund (1986), por exemplo, ou South Lake Street Appartments 2, Chicago (1990) - que retratam um edifício ou grupo de edifícios que foram erigidos ao mesmo tempo e portanto pode-se imaginar que encarnem um mesmo desenho, mas fazem o observador sentir que não houve naquele momento nenhum meio de se prever - portanto de planejar - como aquelas estruturas iriam parecer, como elas atingiriam um observador sensível, sintonizado, em uma data futura; ou, um ponto bem relacionado, que influência elas iriam exercer no decorrer do tempo nos habitantes e transeuntes. Nesse sentido as primeiras fotografias urbanas de Struth não apenas exemplificam a indicialidade ou estrutura do traço tradicionalmente associadas à fotografia, elas sistematicamente exploram essa estrutura de tal modo a produzir um efeito de significância aumentada - de uma vez global e minuciosamente detalhada - que ao mesmo tempo se recusa a ser determinado, reduzido a lugares comuns psicológicos ou sociológicos. O próprio efeito é agudamente descrito por Peter Schjedahl, um dos melhores comentadores de Struth, que escreve:

Nós vemos um espaço de passagem formado por estruturas com uma eloquência histórica, cultural, temporal, casual e de utilização vernacular... Uma convicção de significância, como uma pressão no cérebro, cresce em nós. Não é uma questão de nada normalmente "interessante". O lugar é ordinariamente, meramente, real. Ao mesmo tempo, parece um rébus que urge para ser lido, como se secretasse provas de um crime. Nós não sentimos necessariamente que o fotógrafo sabia o segredo. Ele não está brincando conosco. É mais como se ele tivesse um contador Geiger para sentido, cujo medidor aconteceu de ficar louco nessa localização. ${ }^{35}$
Michael Fried

Thomas Demand e suas alegorias da intenção; "exclusão" em Candida Höfer, Hiroshi Sugimoto, e Thomas Struth

35. SCHJELDAHL, Peter. God's Struth. In: The Village Voice, 2 mar. 1998, número da página ilegível.

36. Idem, Epiphany. In: Parkett, n. 51, dez. 1997, p. 168.

37. *N. do T. No original em inglês back-formation, que, em etimologia, é o processo de criar um novo lexema, usualmente pela remoção de afixos reais ou supostos. 0 neologismo resultante é chamado back-formation. 
38. MUSIL, Robert. The man without qualities, 2 vols. Trad. Sophie Wilkins e Burton Pike. Nova lorque, 1995; vol. 11, From the posthumous papers, p. 17581759. Ver também as páginas notáveis sobre imaginar Deus como "o Artista Eterno" (capítulo 50, p. 1222-1230), incluindo-se duas passagens que parecem especialmente pertinentes aqui:

[Ulrich, o protagonista de Musil, escreve em seu diário:] "Uma cidade como a nossa, adorável e velha, com sua marca arquitetural soberba, que no decorrer das eras ergueu-se do gosto cambiante, é uma única testemunha da capacidade para amar e da incapacidade de amar por muito tempo.

A sequência orgulhosa das estruturas dessa cidade representa não somente uma grande história mas também uma mudança constante na direção do pensamento. Vista dessa forma, a cidade é uma mutabilidade que se tornou uma corrente de pedra e que examina-se diferentemente a cada quarto de século a fim de estar certa, no fim, para eras eternas. A sua eloquência muda é aquela dos lábios mortos, e quanto mais encantadoramente sedutora ela é, mais violentamente ela precisa evocar, em seu mais profundo momento de agradabilidade e de expropriação, resistência cega e horror." (p. 1226-1227)

"Se o que nós expressamos com palavras, não importa o quão magníficas elas são, é na maior parte apenas um e às vezes horríveis, sempre impenetráveis, dentre as quais nós precisamos viver." 36 ("Sempre impenetráveis" não é exatamente correto, mas pode-se entender seu ponto). Para Robert Musil, em The man without qualities, um trabalho que carrega uma relação inquietante com a prática fotográfica recente (relembre o interesse de Bustamante pela noção de "sem qualidades" ou a página refeita de Gursky em Untitled XII), são precisamente as marcas e traços de intenções prévias - ou, como Musil escreve, "significados" e "opiniões" - como realizadas pela arquitetura urbana que fornecem a definição para o indivíduo, de outro modo, amorfo. O que segue não aparece no romance mesmo, mas nas "Notas para os Capítulos (1932/33-41)”:

Edifícios - massa de fôlego, condensação em superfícies que apresentam- se...

Liberto de conexões, todo impulso momentaneamente deforma o indivíduo. O indivíduo, que aparece apenas através da expressão, forma-se a si mesmo nas formas da sociedade. Ele é violado e assim adquire superfície.

Ele é formado pelos back-formations ${ }^{* 37}$ do que ele criou. Se alguém retira esses back-formations, o que resta é algo indefinido, disforme. As paredes das ruas irradiam ideologias. ${ }^{38}$

Meu raciocínio é que as paisagens urbanas de Struth que são reticentes, não explícitas mas impregnadas de sentido, foram um elemento crucial no contexto artístico e intelectual em que a iniciativa de Demand, que é quase exatamente antitética - a remoção de seu assunto de todos os traços de intenções prévias, conscientes ou inconscientes, e sua substituição pelas suas próprias intenções conscientes - se desenvolveu.

$$
* * *
$$

A noção de lugar, fundamental tanto para Demand como para Struth no início de sua carreira, faz um paralelo com a arte de uma fotógrafa alemã um pouco mais velha, Candida Höfer. Höfer nasceu em 1944 e estudou na Academia de arte de Düsseldorf entre 1973 e 1982, fez três anos de aulas de cinema com Ole John, depois disso 
fez aulas de fotografia com Bernd Becher junto com Struth, Gursky, Ruff, e outros. Em um aspecto ela se manteve mais fiel que qualquer outro à prática do casal Becher: assim como eles fotografaram sistematicamente estruturas industriais na Europa e na América do Norte, ela também, com pequenos desvios, dedicou sua carreira a fotografar interiores significantes - salas - de todos os tipos, também na Europa e na América do Norte. (Os títulos de suas fotografias consistem na designação do edifício no qual a sala existe, acrescido da cidade, mais o número de tomadas fotográficas feitas no lugar.) Desde o início, Höfer trabalhou com fotografia colorida; por um longo tempo ela se restringiu a uma câmera de $35 \mathrm{~mm}$ que resultava em impressões $38 \times 57 \mathrm{~cm}$ mas no começo de 1997 ela começa a usar uma Hasselblad 6 x $6 \mathrm{~cm}$, que lhe permitia fazer fotografias de $1,5 \mathrm{~m}^{2}$, e desde 2003, ela trabalha com uma câmera $10 \times 12 \mathrm{~cm}$ que a permite fazer imagens ainda maiores se ela assim o desejar. Suas fotografias são geralmente lindas, em um sentido não problemático da palavra, mas por um longo tempo, eu não conseguia ver como seu trabalho pertencia ao argumento central deste livro, e se de fato pertencia. Então um dia, a caminho de uma exposição de seus trabalhos recentes na galeria Sonnabend em Nova Iorque, eu tive um insight.

Antes de relatar este insight, quero lançar um olhar sobre três fotografias representativas de diferentes momentos da carreira de Höfer. Em Museo Civico Vicenza II (1988), um trabalho do início, a câmera está situada quase que exatamente numa posição oposta e a uma distância considerável de um canto de uma grande sala. Na parede da esquerda estão pendurados três pinturas escuras renascentistas ou do século XVII (na verdade, é possível ver duas pinturas e parte de uma terceira); nós vemos principalmente seus contornos, o que sugere que as duas pinturas de cima, com a moldura superior arredondada, originalmente pertenciam a uma outra sala, provavelmente uma igreja ou refeitório. À direita da mais baixa das três pinturas há uma porta de madeira escura com painéis de vidro emoldurados por uma bonita esquadria, e à direita da porta a uns trinta e tantos centímetros da parede, há um grande globo terrestre secular dentro de uma vitrine com base e estrutura de madeira sextavada. Pouco mais à direita um globo terrestre menor está em uma vitrine menor com pés de madeira. A parede da direita está tomada por duas fileiras de janelas, duas grandes abaixo, e duas pequenas acima; as janelas estão cobertas por cortinas

\section{Michael Fried}

Thomas Demand e suas alegorias da intenção; "exclusão" em Candida Höfer, Hiroshi Sugimoto, e

Thomas Struth

significado, uma opinião, então o que nós expressamos sem palavras é sempre um.

"Portanto eu digo: Nossa realidade, na extensão em que ela depende de nós, é na sua maior parte somente uma expressão de opinião, embora nós atribuemos a ela todo tipo imaginável de importância. Nós podemos dar a nossas vidas uma manifestação específica nas pedras dos edifícios: isso é sempre feito pelo bem de um significado que nos imputamos a elas... Por algum tempo Agathe e eu temos sido sensíveis a uma assombração no mundo empírico. Todo detalhe através do qual o nosso entorno se manifesta 'fala para nós'. Isso significa algo. Isso mostra que isto veio a se tornar um ser com um propósito que não é, de forma alguma, fugaz. Isto é, com certeza, apenas uma opinião, mas ela aparece como uma convicção. É apenas uma ideia súbita, mas ela age como se fosse uma vontade inabalável...

“Parece ser obstinação, mas isso me permite compreender o que eu vejo se além disso eu noto: Esta oposição entre a auto-obsessão que explode do peito de todas as coisas que nós criamos em todo seu esplendor, e o traço secreto de ter sido largado e abandonado, que igualmente começa com o primeiro minuto, está total e completamente de acordo com eu chamar tudo meramente uma opinião. Dessa forma nós reconhecemos que estamos em uma situação peculiar. Pois toda atribuição de 

dissolvendo qualquer detalhe da estrutura interna das janelas, testemu-

sentido mostra a mesma dupla peculiaridade: enquanto é novo nos deixa impaciente com todo sentido oposto lquando guarda-sóis vermelhos estão tendo o seu dia, os azuis são 'impossíveis' - mas algo similar é também verdade sobre nossas convicções); e ainda assim a segunda peculiaridade de todo sentido é que ele é, não obstante, abandonado com o tempo, inteiramente de sua própria iniciativa e com a mesma certeza, quando não é mais novo. Uma vez eu disse que a realidade suprime-se a si mesma. Isso poderia agora ser colocado desta forma: Se o homem está na maior parte do tempo apenas proclamando sentidos, ele nunca está totalmente e continuamente proclamando a si mesmo; mas mesmo que ele nunca possa expressar-se completamente, ele vai tentálo nos modos mais variados, e ao fazer isso ele adquire história." (p. 1228-1229). Uma última passagem, do capítulo 22, ajuda a atingir o ponto: Enquanto estava preocupado com tudo isso [Ulrich] estava olhando os bondes passarem, esperando por aquele que o levaria de volta o mais perto possível ao centro da cidade.

Ele viu pessoas subindo e descendo dos bondes, e seu olho tecnicamente treinado brincava distraidamente com a interação entre soldagem e fundição, rolamento e avanço, engenharia e acabamento a mão, desenvolvimento histórico e o estado da arte atual, que se combinavam pra nha a duração da exposição requerida para fazer a fotografia (é possível intuir que o interior da sala devia ser um tanto quanto escuro). Mais acima, na imagem, é possível vislumbrar um pedaço do teto entalhado, e o terço inferior da imagem é tomado por um piso de mármore polido de um marrom quente que brilha refletindo a luz das janelas. (Os reflexos, naturalmente, estão orientados relativamente à posição da câmera, mas é possível notar como manchas de luz das janelas caem no chão em ângulos diferentes, incidentalmente revelando a estrutura interna das janelas, que de outra forma estaria invisível). Finalmente, abaixo na parede da direita, entre as janelas, estão o que parecem ser sistemas modernos de aquecimento, do que pode-se intuir que a fotógrafa não fez nenhum esforço para disfarçar a natureza historicamente composta da própria sala.

Outro trabalho característico, Neue Nationalgalerie Berlin VII (2001), representa o piso de entrada do Museu de Arte Moderna de Mies van der Rohe em Berlim. O formato quadrado remete à Hasselblad com a qual a imagem foi produzida, e o ponto de vista, paralelo à parede de vidro de fundo, produzindo portanto uma sensação de um único ponto de perspectiva (como nas cenas de rua de Struth), é típica do trabalho mais recente de Höfer. Novamente, a exposição parece ter sido relativamente longa: tanto que as árvores e edifícios detrás da parede de vidro estão bastante desbotados, e os reflexos de luz sobre o chão de pedras incrustadas, que ocupa a metade de baixo da imagem, são suficientemente intensos a ponto de dissolver a porção mais distante do plano do chão. O teto com suportes recuados e travessas de metal vermelhas ocupa a maior parte da metade superior da composição. Mais ou menos ao meio do saguão e à esquerda do centro, uma larga coluna de mármore cinza-esverdeado - que mais parece uma parede curta e independente - conecta o piso ao teto; imediatamente em frente da coluna duas cadeiras Barcelona e um pequeno banco; e aproximadamente a meio-caminho entre a coluna e a câmera atravessa a imagem da esquerda para a direita uma linha de bancos Barcelona ritmicamente alinhados (o último dos bancos é cortado pela margem direita da imagem). Também próximo a esta margem direita há uma estrutura de madeira, cuja função o observador mal pode adivinhar.

Um trabalho mais recente, Ca'Dolfin Venezia I (2003), apresenta 
um maravilhoso salão ornamentado, embora pequeno, de um palácio veneziano. Esta parece ser uma sala onde performances musicais ou de outro tipo acontecem (se este era realmente seu uso original, não fica claro); de qualquer forma a fotografia foi feita de um ponto de vista levemente elevado - como se sobre uma escada ou plataforma - e novamente a parede do fundo, com três espelhos de estilo rococó, está em paralelo ao plano da fotografia. Uma vez mais, também, a composição é rigorosamente centralizada: o observador vê, logo abaixo, aproximadamente dez fileiras de cadeiras estofadas em tecido avermelhado, divididas em dois grupos à esquerda e à direita, com um assoalho de madeira encerado visível entre eles; também é possível ver acima o teto com afrescos, levemente côncavo, no qual estão pendurados dois espetaculares candelabros ornamentados em cristal branco e com longas velas artificiais (com lâmpadas elétricas em suas pontas). Ao fundo e à direita da sala, duas janelas altas delimitadas por drapeados vermelhos permitem que a luz invada a cena e, como nos outros trabalhos, a longa exposição utilizada desbota completamente as próprias janelas. Devido à posição central da câmera, as janelas estão refletidas no espelho da direita da parede do fundo. Em outra fotografia do palácio Veneziano de Höfer, Palazzo Zenobio Venezia III (2003), a fotógrafa e sua câmera aparecem nitidamente refletidas num dos espelhos da parede de fundos, mas não é o caso neste trabalho apresentado aqui ${ }^{39}$. Diferentemente de Museo Civico Vicenza II e Neue Nationalgalerie Berlin VII, ambos com composições econômicas, mais austeras, Ca'Dolfin Venezia I é repleta de detalhes sensuais, cuja riqueza, logo se pode perceber, vai além da habilidade que o olho sozinho pode registrar e desfrutar.

Estes três trabalhos não encapsulam de forma alguma o alcance dos trabalhos de Höfer, mas consistem numa boa base para discussão. Uma maneira de começar essa discussão é notar que todos os críticos do trabalho de Höfer têm denotado a ausência de pessoas nos seus ambientes. (De fato essa ausência não é absoluta; por exemplo, BNF Paris XX (1998), uma vista da sala de leitura de periódicos da Bibliothèque Nationale na rua Richelieu, representa pesquisadores sentados em mesas e de fronte às máquinas de microfilme; mas esta é uma exceção, e no final o efeito da imagem não é essencialmente diferente de todas as outras que não contam com a presença humana). Na verdade, uma exposição retrospectiva de 2005 de Höfer, foi intitulada de "Arquitetura da Ausência”, frase que pretende aludir tanto à ausência de

\section{Michael Fried}

Thomas Demand e suas alegorias da intenção; "exclusão" em Candida Höfer, Hiroshi Sugimoto, e Thomas Struth

fazer estas barracas-sobrerodas que estas pessoas estavam usando.

“Como um último passo, um comitê do departamento municipal de transporte vem à fábrica e decide qual tipo de madeira usar para laminar, a cor da tinta, estofamento, braços nos assentos e alças para as pessoas que ficam em pé, cinzeiros, e assemelhados", ele pensou ociosamente, "e é precisamente esses detalhes triviais, juntamente com a cor vermelha ou verde do exterior, e como eles se balançam degraus acima e para dentro, que para dezenas de milhares de pessoas se constitui no que eles lembram, tudo o que experienciam, de toda genialidade que entrou ali. Isto é o que forma o seu caráter, dota-os com velocidade e conforto; isto é o que os faz perceber os carros vermelhos como lar e os azuis como estrangeiros, e soma-se ao odor inconfundível de incontáveis detalhes que se agarram ao tecido dos séculos." Então não havia como negar - e isto subitamente retornou à linha principal do pensamento de Ulrich - que a vida mesma amplamente se esgota em realidades triviais ou, para colocá-lo tecnicamente, que o poder do seu coeficiente espiritual é extremamente pequeno. (p. 943-944) Pode ser que toda linha de especulação que Musil atribui a Ulrich nesta e em outras passagens fosse impensável antes da fotografia. 

para descrever seu próprio projeto $)^{40}$. O tratamento magistral de luz alcançado por Höfer é uma chave para esta questão, como reconhece Lombino. Ela acrescenta: "No entanto, Höfer não somente revela essas duas qualidades" - luz e vazio - "em suas redutivas imagens de salas vazias, mínimas, mas também em suas imagens mais barrocas de salas ornamentadas cheias de detalhes e inúmeros objetos idênticos, o que poderia conflitar com a ideia de vazio e colocar um desafio composicional. Höfer supera esse obstáculo enfatizando a simetria e o alinhamento inerente em seus assuntos, criando trabalhos que personificam ambos, abundância e vacuidade” (p. 25). Lombino também sublinha a erradicação da desordem de Höfer "para alcançar uma completa clareza e evocar a tranquilidade" (p. 26). No mesmo sentido, Constance W. Glenn, outra das curadoras, escreveu que o formato quadrado que Höfer acrescentou a seu repertório em 1994 "produziu o efeito de enfatizar a quietude etérea de seus espaços - uma quietude que desafia o peso natural do detalhe arquitetural." ${ }^{41}$

Noções como tranquilidade isolada e quietude etérea estão relacionadas ao efeito de distância, outra característica de sua arte, como

39. A reflexão dela aparece em outras palavras também. Ver DIERS, Michael. A physiognomy of public interiors: notes on Candida Höfer's city images. In: Candida Höfer: Hamburg. Cologne, 2002, p. 103 e 108.

40. LOMBINO, Mary-Kay. Inner order. In: Candida Höfer: architecture of absence, catálogo de exposição. Long Beach, West Palm Beach, Provo, 2005-2007, p. 25.

(Futuras referências a páginas deste ensaio estarão entre parêntesis no texto.)

41. GLENN, Constance. Candida Höfer: absence in context. In: ibidem, p. 18.

(Futuras referências a páginas deste ensaio estarão entre parêntesis no texto.) pudemos ver. E além de todas essas qualidades, há a questão primordial da relação do observador com a imagem fotográfica. Com isso me refiro à questão de até que ponto e em que sentido o espectador é convidado a "entrar" no ambiente representado, ou é impedido de fazê-lo, apesar da clareza da mise-en-scène.

O que faz disso uma pergunta complicada de se responder é, em primeiro lugar, que todas as suas imagens estão irrestritamente abertas ao olhar do observador - não há a sensação de coisas escondidas da vista, enquanto que o uso da lente grande angular, a nitidez de foco em toda a superfície, e a pura duração da exposição significam que o espectador está habilitado a ver muito mais e em maior detalhamento do que seria possível se ele ou ela estivesse olhando a própria sala (como eu mesmo já sugeri). E segundo, que os ambientes estão cheios de objetos de uso - mesas, cadeiras, bancos, portas, rampas, luminárias, arquivos de cartões, livros, lances de escada, e por aí vai. Um terceiro fator convidativo é a especificidade histórica de muitos de seus temas, nos quais o espectador reconhece a conotação de um estilo de vida particular: o 
mundo social original do museu Mies não é o mesmo do Ca'Dolfin, e não tem muito em comum com o mundo social ou mundos evocados no Museo Civico Vicenza II. A esse respeito, as fotografias de Höfer podem parecer oferecer acesso a reinos de experiência desaparecidos. Mesmo assim, eu acho que o espectador sente que é rigorosamente "excluído" (a partir daqui eu vou deixar de usar as aspas) dos ambientes de Höfer, exceto no que diz respeito ao sentido de uma visão operacional em um modo quase totalmente sem corpo. Apesar do fato de que os ambientes reais são em si, evidentemente, lugares que de formas incontáveis são fenomenologicamente ligados a atividades de seres humanos, o espectador de suas fotografias não é levado a responder empaticamente a estas ligações (mais do que num grau mínimo, por assim dizer) - imaginar estar sentado nas cadeiras do Ca'Dolfin ou negociando no amplo piso do Museo Civico ou na Neue Nationalgalerie - mas ao inverso, o espectador é induzido a investigar a imagem em questão com uma mistura de um estado de alerta visual intensificado e um desprendimento corporal explícito. Uma imagem emblemática nesse sentido, quase didática, é Ballettzentrum Hamburg III (2001), com sua cadeira funcional comum - da professora de ballet? - isolada no meio de um amplo estúdio de dança. Não é uma cadeira que cativa o observador a aproximar-se ou a sentar-se nela. Mas ao mesmo tempo, esses ambientes atingem por eles mesmos o espectador como inquestionavelmente reais, compreensíveis, pelo menos à primeira vista, enquanto continuidade de seu próprio domínio experimental. (O que estou querendo dizer é que a sensação de exclusão dos espaços nas fotografias de Höfer não está nem perto do sentido radical da "separação"*42 que eu associei com o trabalho artístico de Gursky. Nem por isso quero dizer que suas fotografias incitam uma repulsa ao observador como faz o Tableaux de Bustamante, ou exploram um ponto de "saturação" como nas imagens de Demand. Talvez elas continuamente encontrem sentido na ênfase de sua "opticalidade", para usar um termo da minha crítica dos anos 1960, que Jeff Wall usou recentemente para suas próprias fotografias. ${ }^{43}$ Então, quando Lombino sustenta que as imagens de Höfer "revelam somente os traços das atividades que estão incorporados nos detalhes dos trabalhos" (p. 24), tudo depende do que ela quer dizer com "traços" e com "incorporados". Por outro lado, os ambientes individuais são, de fato, como ela sugere, quase sempre tratados como "lugares para encontros culturais e intercâmbios sociais" (p. 24); por outro lado, mesmo

\section{Michael Fried}

Thomas Demand e suas alegorias da intenção; "exclusão" em Candida Höfer, Hiroshi Sugimoto, e Thomas Struth

42. *N. do T. Fried usa o termo "severing" (separação) para acentuar a distância, o impedimento entre observador e o espaço representado na fotografia de Gursky em outros momentos do livro.

43. Ver WALL, Jeff. Post60s photography and it's modernist context: a aonversation between Jeff Wall and John Roberts. In: Selected essays and interviews, p. 340-341; eu cito as observações de Wall no capítulo 3, n. 41.

44. Cf. Julian Heynen: "Quando as pessoas que pertencem a esses espaços - traços das quais são vistos em todos os lados - não estão presentes nas imagens, então é como se os espectadores entrassem e ocupassem o lugar com seu olhar. Enquanto os outros estão fora, os espectadores se demoram nesse lugar neste lugar estrangeiro. É um pouco como a situação de um ladrão ou um detetive ou qualquer um que tenha involuntariamente tropeçado no território de outra pessoa. 

dos globos terrestres, aquelas que entraram na primeira construção do edifício, aquelas que entraram no design do museu moderno - não há nada dos rastros de sua estrutura que salte à vista - a evidência material do desgaste, de anos de muito uso, de contínua habitação, alteração e deterioração - encontrados nas primeiras paisagens urbanas de Struth, por exemplo. Isto também depõe contra qualquer outro significado que não seja uma exploração estritamente visual do lugar representado. ${ }^{44}$

$\mathrm{O}$ insight em relação às fotografias de Höfer, que citei acima, diz respeito a algo que esbocei no livro "Art and objecthood", em que chamava a atenção para a importância de uma teoria minimalista/literalista

As razões desconhecidas para a ausência dos outros e seu possível retorno para o lugar 'deles' aumentam a percepção do espectador como "intruso"' (Venice 2003.

In: Candida Höfer/Martin Kippenberger/Venedig 2003, catálogo de exposição. Venice, 2003, p. 92). Novamente, tudo depende do que Heynen quer dizer com traços; a ideia de que o espectador se sente um "intruso" me parece certa. Outro comentador, Michael Diers, compara os interiores de Höfer com aqueles do pintor e desenhista alemão do século dezenove Adolph Menzel, um dos artistas mais empáticos de todos os tempos (A physiognomy of public interiors, p. 110-112).

Eu não concordo. Ver, para essa conexão, FRIED, Michael.

Menzel's realism: art and embodiment in NineteenthCentury Berlin. Londres e New Haven, 2002. 45. MORRIS, Robert. Notes on sculpture, part 2. In: Continuous project altered daily, p. 16.

45. MORRIS, Robert. Notes on sculpture, part 2.

In: Continuous project altered daily, p. 16. para a prática da disposição de um dado trabalho em um tipo particular de espaço interior. Nas palavras de Morris (citadas por mim):

Pois o espaço da própria sala é um fator estruturante, tanto em sua forma cúbica quanto em termos do tipo de compressão que tamanhos e proporções diferentes de espaços podem provocar sobre os sujeitos e os objetos. [Morris está imaginando o sujeito - o observador - encontrando com um trabalho literalista dentro de um espaço cúbico de uma galeria.] O fato do espaço da sala se tornar tão importante não significa que uma situação ambiental esteja estabelecida. O espaço total é, com sorte, alterado de maneira intencional pela presença do objeto. Isto não é controlado no sentido de ser ordenado por um agrupamento de objetos ou por uma configuração do espaço em torno do espectador. (p. 154) ${ }^{45}$

Na minha interpretação:

O objeto, e não o observador, deve permanecer o centro ou foco da situação, mas a situação em si pertence ao espectador - a situação é dele. Ou como Morris observou, "eu quero enfatizar que as coisas estão no espaço com o sujeito, ao invés de... [o sujeito] estar no espaço circundado por coisas.” Novamente, não há uma distinção clara ou precisa entre os dois estados: uma pessoa está, afinal, sempre rodeada por coisas. Mas, as coisas que são trabalhos/obras de arte literalistas devem de alguma maneira confrontar o espectador - deveriam, se poderia quase dizer, ser colocadas não apenas em seu espaço, mas em seu caminho... (p. 154, grifos no original) 
Aqui é onde a sala - o interior da galeria - entra como arena ideal para os tipos particulares de enfrentamentos que "Art and objecthood" buscou analisar, enfrentamento no qual, como já foi observado, o objeto literalista é, ele mesmo, substituído pela experiência do sujeito encarnado que está em andamento e é, em princípio, aberta, não somente deste objeto mas também da situação total em que o sujeito encontra a si mesmo em virtude de simplesmente entrar na sala (p. 163). "O conceito de uma sala é, na maioria das vezes clandestinamente, importante para os trabalhos de arte literalistas e sua teoria", eu observei em uma nota de rodapé. "De fato, ela frequentemente pode ser substituída pela palavra 'espaço': diz-se que algo está em meu espaço se está na mesma sala que eu (e se aquilo estiver colocado de uma maneira impossível de não se notar)” (p. 170, n. 14).

Seguindo a mesma linha, ainda que não criticando o minimalismo, Dan Graham escreveu em 1985:

Enquanto a pop art da América do Norte do início dos anos 1960 referia-se ao entorno do meio cultural como moldura, o trabalho de arte "Minimalista" de final dos anos 1960 pareceria estar se referindo ao cubo interior da galeria como a derradeira moldura contextual de referência ou suporte para o trabalho. Esta referência era somente composicional; no lugar de uma leitura composicional interna do trabalho, a galeria comporia a estrutura formal do trabalho em relação à estrutura arquitetônica da galeria. Que o trabalho fosse igualado ao seu continente arquitetônico tendia a literalizá-lo; tanto o continente arquitetônico quanto o trabalho por ele contido foram feitos para serem vistos de maneira não ilusionista, neutra e objetivamente factual - quer dizer, simplesmente como matéria. A galeria funciona literalmente como parte da arte. ${ }^{46}$

(Do meu ponto de vista tal declaração, embora verdadeira, deixa de mencionar, sem dúvida porque toma como já dado, a primazia do sujeito da experiência.) As observações de Graham estão destinadas a atingir o leitor informado recordando, não somente "Art and objecthood" mas outro texto também: No interior do cubo branco: a ideologia do espaço da galeria, de Brian O'Doherty, um livro curto que consiste em quatro ensaios, cujos três primeiros foram publicados pela primeira vez na Artforum em 1976. A tese de O’Doherty é de que o cubo branco do interior da galeria moderna tem papel fundamental, embora na maior
Michael Fried

Thomas Demand e suas alegorias da intenção; "exclusão" em Candida Höfer, Hiroshi Sugimoto, e Thomas Struth

46. GRAHAM, Dan. My works for magazines pages: "a history of conceptual art" (1985). In: ALBERRO, Alexander e STIMSON, Blake (eds.). Conceptual art: a critical anthology. Cambridge, 1999, p. 419. 
Ou melhor a história da arte moderna pode ser correlacionada com as mudanças nesse espaço e na maneira como o vemos. Chegamos a um ponto em que primeiro vemos não a arte, mas o espaço em si. (Um clichê atual é elogiar o espaço ao entrar na galeria.) Vem à mente a imagem de um espaço branco ideal que, mais do que qualquer quadro isolado, pode constituir o arquétipo da arte do século $\mathrm{XX}$; ele se clarifica por meio de um processo de inevitabilidade histórica comumente vinculado à arte que contém.”48

\section{Dois parágrafos à frente, também são relevantes:}

A galeria é construída de acordo com preceitos tão rigorosos quanto os da construção de uma igreja medieval. O mundo do exterior não deve entrar, de modo que as janelas geralmente são lacradas. As paredes são pintadas de branco. O teto torna-se a fonte de luz. O chão de madeira é polido, para que você provoque estalidos austeros ao andar, ou acarpetado, para que você ande sem ruído. A arte é livre, como se dizia, "para assumir vida própria". Uma mesa discreta talvez seja a única mobília. Nesse ambiente, um cinzeiro de pé torna-se quase um objeto sagrado, da mesma maneira que uma man-

47. N. do T. As citações do livro No interior do cubo branco, de Brian O'Doherty, foram retiradas da edição brasileira, traduzida por Carlos Mendes Rosa.

48. O'DOHERTY, Brian. Inside the white cube: the ideology of the gallery space, edição expandida. Berkeley, Los Angeles, Londres, 1999, p. 14. (Futuras referências a páginas deste livros estarão entre parêntesis no texto.]

49. N. do T. “O último modernismo é o período final do modernismo; termina com a morte de Pollock" (sic).

50. N. do T. Sem (em francês no original). gueira de incêndio num museu moderno não se parece com uma mangueira de incêndio, mas com uma charada artística. Completa-se a transposição modernista da percepção, da vida para os valores formais. Esta, claro, é uma das doenças fatais do modernismo.

Sem sombras, branco, limpo, artificial - o recinto é consagrado à tecnologia da estética. Montam-se, penduram-se, espalham-se obras de arte para estudo. Suas superfícies imaculadas são intocadas pelo tempo e suas vicissitudes. A arte existe numa espécie de eternidade de exposição e, embora haja muitos "períodos" (último Modernismo ${ }^{49}$ ), não existe o tempo. Essa eternidade dá a galeria uma condição de limbo; é preciso já ter morrido para estar lá. Certamente a presença daquela estranha peça de mobília, seu próprio corpo, parece supérflua, uma intromissão. O recinto suscita o pensamento de que, enquanto olhos e mentes são bem-vindos, corpos que ocupam espaço não o são - ou são tolerados somente como manequins cinestésicos para estudo futuro. Este paradoxo cartesiano é reforçado por um dos ícones da nossa cultura visual: a foto da exposição, sans ${ }^{50}$ pessoas. Nele, enfim, se elimina 
o espectador, a própria pessoa. Você está lá sem estar lá - um dos maiores préstimos concedidos à arte por sua antiga adversária, a fotografia. A foto da exposição é uma metáfora do recinto da galeria. Consuma-se nela um ideal com tanta intensidade quanto numa pintura de Salão dos anos 1830. (p. 15)

Talvez já esteja claro para onde tende meu argumento. Eu sugiro que um ponto fundamental de referência para as fotografias de interiores de Höfer, ela esteja ou não consciente disso, é o espaço moderno da galeria, ao qual suas imagens aludem e criticam em vários aspectos específicos. Quanto a essa alusão há, não somente o vazio desses ambientes e a claridade transcendente com a qual eles são representados, mas também aquilo que Glenn descreve como: "seu manuseamento sutil, mas ricamente matizado da cor, caracterizado por um uso cativante da gama de branco" (p. 19, grifos meus). Como Glenn apropriadamente observa:

[Höfer] escolhe deixar que o branco defina a maior parte de suas composições, dos mais sutis contrastes que iluminam detalhes arquitetônicos ou refinando a percepção do espaço, aos motivos destacados pelas formas repetidas, como as fileiras e mais fileiras de mesas de leitura impecáveis da biblioteca. Olhe atentamente as imagens como um todo. O efeito irresistível está na sua tonalidade pálida, impregnada de luz. Em uma porção - que geralmente ocupa ligeiramente mais ou menos metade da composição - o branco domina, equilibrado pela escuridão da área em contraste, que normalmente é iluminada por reflexo. (p. 19)

As observações de Glenn se encaixam perfeitamente nas fotografias de Höfer que eu vi, assim como a outras tantas, mais antigas ou mais recentes, como em DHFK Leipzig IV (1991), Schindler House Los Angeles VII (2000), e a espetacular Ca'Rezzonico Venezia I (2003), três imagens de tipos de interiores muito diferentes, que não obstante pertencem a uma singular sensibilidade colorística.

Não há dúvida de que a predileção de Höfer por ambientes brancos (e luz branca) tem uma raiz temperamental. A verdade é que a tonalidade forte do branco em sua arte remonta à brancura imaculada da galeria modernista, assim como aquilo que pode ser chamado do sem-vestígio ${ }^{51}$ dos seus interiores (note as superfícies "desencardidas" dos trabalhos modernistas que O'Doherty caracterizou de "intocadas pelo tempo e suas vicissitudes"). Quanto à crítica, há
Michael Fried

Thomas Demand e suas alegorias da intenção; "exclusão" em Candida Höfer, Hiroshi Sugimoto, e Thomas Struth

51. N. do T. Do inglês tracelessness: sem traço, rastro ou vestígio. 

articulados; por outro lado, as janelas não estão vedadas para que o mundo exterior não possa entrar, em vez disso são fontes cruciais e características da brilhante iluminação; e por último, a ênfase nas suas fotografias está só ocasionalmente nas paredes, que na maioria das imagens estão subordinadas aos pisos, tetos, iluminação e aos vários objetos como mesas, cadeiras, estantes, espelhos, janelas, luminárias, estátuas, e similares. De um modo geral, a "intemporalidade" - também a "não lugaridade" 52 - do espaço da galeria moderna é contradito pela especificidade histórica e geográfica dos seus lugares diversos e cuidadosamente escolhidos.

Uma outra questão concerne o status do expectador, e aqui, precisamente com respeito ao minimalismo, a insistência de O'Doherty de que a galeria modernista é hostil ao sujeito incorporado sofre certa modificação. Em suas palavras:

52. “Existe uma inquietação peculiar em olhar trabalhos de arte que tentam estabelecer território mas não lugar no contexto da galeria moderna sem lugar" libidem,

p. 27). (N. do T. do inglês placelessness: entendido aqui como não lugar, ou um lugar que é geral, sem identidade, que tenta ser neutro, seria da neutralidade da galeria moderna.)

53. N. do T. Cf. tradução de No interior do cubo branco, op. cit., p. 55.
No final dos anos 60 e 70, Olho e Espectador [o último sendo um vestígio ou fantasma do sujeito totalmente incorporado] negociam algumas transações. Os objetos por mais diminutos, sempre provocaram percepções não só visuais. Embora o que estivesse lá se revelasse instantaneamente para o olho, era preciso verificar melhor: não fosse assim, qual o sentido da tridimensionalidade?

Aqui há dois tipos de período de tempo: o olho apreendia o objeto de uma só vez, como na pintura, e depois o corpo o levava ao redor do objeto. Isso estimulava um feedback entre a expectativa confirmada (verificação) e a sensação corporal subliminar até então. Olho e Espectador não estavam unidos, mas cooperavam neste momento. O Olho bem acurado recebia algumas informações residuais de seu corpo abandonado (a cinestesia da gravidade, do movimento, etc.) Os outros sentidos do Espectador, sempre em estado bruto, eram impregnados com algumas percepções precisas do Olho. $\mathrm{O}$ Olho comandava o movimento do corpo para lhe dar informações - o corpo torna-se um coletor de dados. Há um tráfego intenso nos dois sentidos dessa rodovia sensorial - entre a sensação conceituada e o conceito efetivado. Nessa aproximação instável encontra-se a origem dos cenários de percepção, performance e Body Art. (p. 50-52 $)^{53}$. 
Eu tenho reservas quanto a isto como uma paráfrase do projeto minimalista/literalista (da noção de "controle", os dois tipos de tempo, o corpo que "carrega" o olho), assim como eu não compartilho a visão de O'Doherty de que na pintura modernista antes do minimalismo, o corpo era visto com "supérfluo, um intruso" (toda a distinção que percorre o livro entre o Olho e o Espectador me parece forçada, assim como o argumento de que "é preciso ter morrido" para estar no espaço da galeria modernista). No entanto, O’Doherty e eu concordamos que o minimalismo dirigia-se à experiência corporal de uma nova maneira, e aqui a diferença entre a sala minimalista/literalista (como discutido em "Art and objecthood") e os interiores de Höfer, com a sua calculada exclusão do espectador, é de fato intensa. A ubiquidade dos reflexos nas imagens de Höfer, talvez mais dramaticamente exemplificada por DHFK Leipzig IV com seu superpolido piso de ginásio refletindo o brilho vindo das fileiras de janelas através das quais a luz inunda o vasto ambiente (aqui também o brilho joga contra a verdadeira entrada de luz natural que chega do canto superior direito até o canto inferior esquerdo), também trabalha contra a ideia minimalista ainda mais fortemente que contra a modernista, pela simples razão de que o piso como tal assim como o solo dos movimentos do espectador corporificado e um importante contexto para a localização de objetos individuais - desempenha um papel mais enfático no minimalismo do que no modernismo (basta imaginar tentar se resolver com uma das peças quadradas de metal de Carl Andre instalada naquele piso de ginásio). Assim também faz a frequente escolha de Höfer por pontos de vista elevados, que distancia-se radicalmente daquele de qualquer observador possível que pudesse entrar a pé no verdadeiro ambiente.

Uma última característica do relato sumário de O’Doherty sobre o espaço da galeria modernista merece atenção: sua reivindicação de que a "foto da exposição, sans pessoas," captura algo da essência da experiência da ida à galeria modernista. "Aqui ao menos o espectador, ele mesmo, é eliminado" - completamente, ele parece dizer. Obviamente eu penso que isto é exagerado como uma caracterização da experiência modernista, mas o que as observações de O’Doherty sugerem de forma interessante - e nisto, também, eu concordo com ele - é que através da tomada da exposição, a fotografia efetivamente exclui o espectador da cena representada. ("Você está lá, sem estar," como ele coloca). Neste sentido, a fotografia de exposição como descrita por O’Doherty anteci-
344

Michael Fried

Thomas Demand e suas alegorias da intenção; "exclusão" em Candida Höfer, Hiroshi Sugimoto, e Thomas Struth

54. Os ensaios de O'Doherty são citados em relação ao "Art and objecthood" de Mark Linder, como segue: "Ao construir seu argumento [em 'Art and objecthood'] em torno de uma oposição entre as palavras 'espaço' e 'quarto', o próprio Fried 'deixa de notar' o relacionamento dialético e histórico entre a ascensão do 'objeto' de arte e a galeria de arte moderna e o museu de arte: quer dizer, um gênero específico de arquitetura que Brian O'Doherty alegorizou posteriormente como 'o cubo branco'. Somente com a emergência da galeria de arte com paredes brancas, esvaziada, com pé direito alto como um tipo comum de 'quarto' a pintura e a escultura modernistas poderiam manter o mito da autonomia" (Nothing less than literal: architecture after minimalism. Cambridge e Londres, 2004, p. 125). A reivindicação maior de Linder, que me parece correta, é que meus escritos sobre modernismo quase sem exceção reprimem o pensamento sobre arquitetura, que implicitamente desempenha um papel negativo (i.e.

"teatral") na minha crítica. 

até mesmo da fotografia de exposição mais artificiosa, na exploração de seu rico e variado motivo principal. ${ }^{54}$

55. Isso é dito por Sugimoto em Contacts Hiroshi

Sugimoto (2000), um filme curta-metragem de JeanPierre Krief Itradução minha da tradução francesa das observações de Sugimoto de Rose-Marie Makino Fayolle). Em um artigo de 1997, Monty DiPietro escreve: "Para conseguir o efeito de mar poeirento em Norht Atlantic Ocean, Cape Town Island (1996)", um trabalho então em exposição na Galeria Koyanagi na faixa Ginza em Tokio, "Sugimoto arrastou sua câmera norte-americana Durdof and Sons com gabinete de madeira para Newfoundland, montada em um tripé francês, com lentes Carl Zeiss de rosca, carregada com uma folha de filme $8 \times 10$ de Kodak Plus- $X$ iso 125 e então colocou um filtro de média densidade no aparato difícil de manejar para reduzir a sensibilidade do filme bem abaixo de um iso. 'É como a velocidade de um filme do século XIX, quando a fotografia foi inventada', ele explica. Quando ele estava satisfeito com a luz e a composição ele acionou o disparador e esperou uma hora e meia para a paisagem marinha se queimar no filme" (Hiroshi Sugimoto at the Koyanagi Gallery.

Disponível em: $<$ http://www. assemblylanguage.com/ reviews/Sugimoto.html $\rightarrow$ l.

56. Contacts Sugimoto. Lê-se em francês: "Dès que l'on commence à entrer dans les détails de l'eau, on s'y noie".
$* * *$

Há espaço neste capítulo para somente algumas breves observações sobre quatro corpos de trabalho - as "Seascapes" em preto e branco de Sugimoto, que ele começa a fazer em 1980 e que hoje já ultrapassam as centenas; as fotografias da série "Paradise" de Struth das florestas e selvas, produzidas entre 1998 e 2001; e dois livros fotográficos de animais em zoológicos, The Animals (1969), de Winogrand, e Zoologische Gärten (1993), de Höfer, que quase exigem ser comparados uns aos outros.

Sobre a primeira das "Seascapes" de Sugimoto, uma fotografia do mar do Caribe feita na Jamaica em 1980, o artista explicou que estava num penhasco acima do mar, "não muito alto, provavelmente uns 10 metros mais ou menos acima do nível do mar. O lugar era prático para uma observação do oceano: nenhum barco, ou iate, ou navio, somente a água e o céu. Aquilo era o que eu queria. Eu decidi manter sempre a mesma composição, com a linha do horizonte como um centro fixo; metade céu, metade água, nada mais." ${ }^{55}$ Para tanto ele fez uma marca no visor da sua câmera para determinar a correta posição da linha do horizonte para todas as fotografias subsequentes. O que significou que todas as "Seascapes" têm a mesma estrutura interna extremamente simples, apesar de também diferirem consideravelmente umas das outras dependendo das condições de luz e clima, e do estado preciso da água. $\mathrm{Na}$ verdade, há fotografias nas quais a linha do horizonte está invisível por causa de neblina ou garoa, mas nestes casos Sugimoto parece ter calculado onde ela estaria, com isto manteve rigorosamente a sua fórmula. Quando alguém encontra uma única "Seascape" numa galeria ou museu, esta pessoa é invariavelmente atingida por sua grandiosidade tranquila. Para o próprio Sugimoto, as imagens quase idênticas compõem uma série vasta e aberta, e ele prefere pensar no observador como sendo convidado a comparar umas com as outras, em quantidade, para notar de uma vez pequenas diferenças - olhando atentamente para cada imagem individualmente ao ponto de afogar-se nelas - e assim tornar-se 
progressivamente mais consciente do que todas elas têm em comum. ${ }^{56}$

Outra maneira que Sugimoto tem de falar de "Seascapes" como um grupo é em termos de uma viagem imaginária no tempo. Em "Seascapes" ele disse, "não há a presença humana. Porque eu tento representar o estado pré-humano da paisagem. É como se eu fosse o primeiro humano a aparecer neste planeta que é a terra. Este primeiro humano que seria eu olha em torno e descobre sua primeira paisagem, uma paisagem marinha. Feita somente de ar e água. É por isso que não há traço humano." ${ }^{57}$ A noção desta falta de rasto ou vestígio ${ }^{* 58}$ relembra tanto as reconstruções de Demand (que carregam apenas os traços de sua manufatura) e os ambientes de Höfer (que, embora sejam "históricos", são também imaculados), enquanto o tema da condição pré-humana é muito sugestivo com respeito à teatralidade - como se as "Seascapes" fossem imaginadas por Sugimoto como representações de tantas cenas elementares quase idênticas que nunca tivessem sido previamente observadas por olhos humanos; na verdade como se, alterando ligeiramente o pensamento de Sugimoto, os "originais" destas cenas tivessem sido vistos apenas pela câmera, não pelo próprio Sugimoto, antes de serem disponibilizadas como representação por meio de suas fotografias.

Ambas observações, de Sugimoto e minha emenda, são claramente ficções, mas há outro sentido, ainda mais fundamental, no qual o espectador, e talvez também o fotógrafo, são excluídos de "Seascapes”. Isso começa a emergir se se considera a relação das imagens individuais com seus títulos, que em todos os casos consiste simplesmente nos nomes dos mares que representam e do lugar de onde foi tirada a fotografia. Para citar três trabalhos mais representativos nesta série: Sea of Japan, Rebun Island (1996); North Atlantic Ocean (1996); e Black Sea, Ozuluce (1991). O que é obviamente impressionante sobre estas é que as cenas nas fotografias são mais ou menos idênticas; mais precisamente, que as diferenças entre elas como podem ser percebidas (e como ressaltado antes, Sugimoto encoraja o discernimento das diferenças) não têm qualquer influência sobre a questão de sua localização. Topograficamente não há diferença nenhuma entre uma "Seascape" e outra: o que acontece por causa da decisão de Sugimoto de buscar sempre o mesmo motivo elementar ao longo de toda a série e de enquadrar sempre de forma idêntica. Com isso, os títulos asseguram ao observador algo que não pode ser visto - que as "Seascapes" foram fotografadas em diferentes lugares. Mais precisamente, os títulos anunciam que o
Michael Fried

Thomas Demand e suas alegorias da intenção; "exclusão" em Candida Höfer, Hiroshi Sugimoto, e Thomas Struth

57. Contacts Sugimoto.

58. * N. do T. Do inglês tracelessness: sem sinal de rasto ou traço humano. 
ARS fotógrafo teve que viajar para diferentes partes do mundo e montar o ano 14 seu equipamento desajeitado e fora de moda sobre uma ou outra linha n. 28 costeira a fim de tirar suas fotos. E isto é crucial para se compreender que Sugimoto não fez tudo isso para mostrar ao observador como estes lugares em questão parecem ser (ninguém consegue reconhecer os lugares pelas fotografias ou vice-versa) mas o fez para que o espectador perceba que o fotógrafo não tirou fotografias de como as paisagens se parecem, entendendo assim que este não é um tipo curioso de falha mas sim um projeto deliberado e ontologicamente ambicioso. Em outras palavras, apesar das aparências, as "Seascapes" não são vistas - o que fica mais claro nas imagens tiradas à noite, que estão entre as mais interessantes da série.*

\section{$* * *$}

*No capítulo 1 deste livro eu discuti várias passagens sobre o voyeurismo em The temple of dawn, de Yukio Mishima, e na conclusão vou discutir After "Spring Snow" by Yukio Mishima, de Jeff Wall, uma fotografia baseada em um episódio do primeiro romance da tetralogia. Aqui, no entanto, eu quero citar uma longa passagem do capítulo de abertura de The decay of the angel, que leva a tetralogia The sea of fertility para um fechamento:

O mar, um mar sem nome, o Mediterrâneo, o mar do Japão, a baía de Suruga aqui diante dele; uma rica, sem nome, absoluta anarquia, capturada após uma grande luta como algo chamado "mar", de fato rejeitando um nome.

Enquanto o céu anuviava, o mar caiu numa contemplação aborrecida, cravejado de finos pontos de rouxinóis coloridos. Ele se eriçou com ondas-espinho, como um ramo de rosas. Nos próprios espinhos havia a evidência de um tornar-se suave. Os espinhos do mar eram suaves.

Três e dez. Não havia navios à vista.

Muito estranho. Todo o vasto espaço estava abandonado.

Não haviam nem asas de gaivotas.

Então um navio fantasma surgiu e desapareceu a oeste.

A Península de Izu estava envolta em neblina. Por um tempo ela deixou de ser a Península Izu. Ela era o fantasma de uma península perdida. Então ela desapareceu inteiramente. E havia se tornado uma ficção num mapa. Tanto navios como a península pertenciam à "absurdidade da existência”.

Eles apareciam e desapareciam. Como eles diferem?

Se o visível era a soma de ser, então o mar, enquanto não estivesse perdido na névoa, existia ali. Ele estava sinceramente pronto para existir. 
Um simples navio mudou tudo.

Toda a composição mudou. Com um rasgo em todo o padrão da existência, um navio foi recebido pelo horizonte. Uma abdicação foi assinada. Todo um universo foi jogado fora. Um navio apareceu, para descartar o universo que havia guardado sua ausência.

Múltiplas mudanças nas cores do mar, momento a momento. Mudanças nas nuvens. E a aparição de um navio. O que estava acontecendo? O que estavam [sic.] acontecendo?

Cada instante trouxe-os, mais momentoso que a explosão do Krakatoa. Apenas ninguém notou. Nós estamos muito acostumados com a absurdidade da existência. A perda de um universo não vale a pena de ser levada seriamente. Acontecimentos são os sinais de contínua reconstrução, reorganização. Sinais de um sino distante. Um navio aparece e dispara o sino a tocar. Em um instante o som faz com que tudo seja seu. No mar eles são incessantes, o sino está tocando eternamente.

Um ser.

Ele não precisa ser um navio. Uma simples laranja amarga, aparecendo ninguém sabe quando. É suficiente para disparar o toque do sino.

Três e trinta da tarde. Uma simples laranja amarga representou estar na baía de Suruga. (Yukio Mishima, The decay of the angel, trad. Edward G. Seidensticker [1971; New York, 1974], p. 8-10)

Nas "Seascapes" de Sugimoto, é claro, não há navios, nem laranja amarga, nunca. Mesmo assim, da perspectiva da passagem acima citada, os mares de Sugimoto, na sua "igualdade" - na sua resistência à identidade, tematizada, como sugeri, pelos seus títulos (ou ainda, pela "falha" dos títulos em capturar qualquer qualidade intrínseca nas imagens como tais) - podem ser consideradas como muitas imagens da mesma "rica, sem nome, absoluta anarquia, capturada após uma grande luta como algo chamado 'mar', de fato rejeitando um nome". Quanto ao visível como a 'soma de ser', uma questão pode surgir, senão são as fotografias de Sugimoto que conferem ser a estes mares, na medida em que estes são tomados como terem sido "visíveis" somente para o olho da câmera. De qualquer forma, uma certa concordância entre o texto de Mishima e as fotografias de Sugimoto parece nada menos que surpreendente.

Meus agradecimentos a Walter Benn Michaels por me ajudar a pensar sobre os aspectos da exclusão do espectador nas "Seascapes" de Sugimoto.
Michael Fried

Thomas Demand e suas alegorias da intenção; "exclusão" em Candida Höfer, Hiroshi Sugimoto, e Thomas Struth 
ano 14

n. 28

59. Vinte e cinco dessas fotos foram reunidas em STRUTH, Thomas. New pictures from

Paradise. Munich, 2002.

60. MASSUDA, Rei. A place for looking: the photographs by Thomas Struth. In: Thomas Struth: my portrait, catálogo de exposição. Tokyo e Kyoto, $2000, \mathrm{~s} / \mathrm{p}$.

61. BIRNBAUM, Daniel. Paradise reframed.

In: Artforum, vol. 40, maio 2002, p. 149.

62. REUST, Hans Rudolf. A thousand words: Thomas Struth talks about his ".'Paradise" Series. In: ibidem, p. 151. (Futuras referências a páginas deste artigo estarão entre parêntesis no texto.) Reust comenta: “Confrontado com uma imagem reticente de uma folhagem indiferenciada, o pensamento do espectador só pode se voltar para dentro.

Nestas fotografias, Struth

encontra os limites de uma

fotografia não discursiva que desenfatiza seu objeto específico através do motivo"

(ibidem).

63. *N. do T. No original: self.

64. WINOGRAND, Garry. The animals. Nova lorque, 2004 [1969] (Posfácio de John Szarkowskil.
Quanto a série "Paradise" de Struth, feita entre 1998 e 2001 em florestas e selvas na China, Japão, Austrália, Brasil, e na Bavária Alemã, nada demonstra mais surpreendentemente o apelo da recente fotografia artística à estratégia da exclusão do que essas grandes e desconcertantes imagens, quase todas elas parecem ter como seu objetivo o confronto do observador com cenas de impenetrável exuberância, densidade, complexidade, não diferenciação. ${ }^{59}$ Surpreendentemente, porque ao longo de sua carreira Struth tem sido o mais empático dos fotógrafos contemporâneos (como demonstram tanto os retratos de família como as paisagens urbanas), o que sugere que as fotografias de "Paradise" representam uma tentativa deliberada de ir contra sua tendência natural no interesse em trazer uma relação diferente, resolutamente não empática entre a imagem e o observador. Em geral, comentadores entenderam que eles estavam sendo postos para fora dessas imagens, mas o que não foi reconhecido é o amplo contexto artístico no qual a exclusão tem emergido como um importante tropo para a ambiciosa fotografia artística. Por exemplo, Rei Masuda escreve: "Pode ser possível identificar espaço para o pensamento se realmente quisermos, mas, face à esmagadora existência das plantas, somos levados a sentir que estas intenções podem esperar.” ${ }^{60}$ E Daniel Birnbaum: "Struth originalmente viu estas densas texturas como um texto ilegível, tão impossível de alcançar como escrita caligráfica para um ocidental destreinado. Portanto uma zona de fenômeno natural aparece além das antinomias da subjetividade, um reino de experiências cruas, mas não inteiramente de alienígenas, do mundo das árvores e plantas e de flores esplêndidas. Pura visibilidade, a carne do mundo, coisas coloridas ao sol.”61 O próprio Struth disse que as fotografias "contém uma abundância de informações delicadamente ramificadas, que torna quase impossível, especialmente em grandes formatos, isolar formas singulares. Alguém pode passar muito tempo em frente destas imagens e permanecer incapaz de saber como lidar com elas". ${ }^{62} \mathrm{O}$ entendimento do próprio Struth de seu projeto é caracteristicamente "espiritual" - as imagens em sua visão "enfatizam o eu"*63 e fornecem ocasiões para meditação e diálogo interno (p. 151). Sem dúvida, isto é verdade, mas sua significância artística mais profunda reside mais além, no espaço carregado entre a fotografia e o observador. 
Finalmente, é instrutivo comparar dois delicados livros de fotografias de animais em zoológicos, The animals, de Winogrand (1969) ${ }^{64}$ e Zoologische Gärten, de Höfer (1993) ${ }^{65}$ - instrutivos porque o contraste entre os respectivos grupos de imagens é gritante, e também porque este contraste pertence à mudança da estética da fotografia de rua em preto e branco, que por volta de 1969 entra numa fase crítica, para uma atitude mais austera e deliberada conectada aos efeitos de exclusão que eu venho examinando neste capítulo (de fato, as fotografias de zoológico de Höfer dificilmente podem ser qualificadas como fotografias de rua em qualquer sentido). Ao invés das inesperadas e frequentemente bem-humoradas justaposições de observadores e animais de Winogrand, com seus primeiros planos inclinados que sugerem seu próprio movimento impulsivo através da cena, e a impressão geral que suas fotografias transmitem de terem sido tiradas nesse movimento ${ }^{* 66}$, e na maior parte em close-up (se não dos animais, pelo menos das pessoas olhando para eles), as fotografias coloridas em grande formato de Höfer são toda frieza, distância, separação, como se registrassem tão neutro quanto possível o simples fato que animais no zoológico habitam um mundo diferente daquele dos visitantes humanos, ainda que também seja verdade que o mundo dos animais como pode ser visto nestas fotografias não é natural mas produzido pelo homem - uma construção artificial desenhada tanto para fornecer aos animais um ambiente adequado como para permitir que os visitantes humanos olhem para os animais a partir de um distanciamento de suas vidas encarceradas. É um mundo de "aparências"*67, em outras palavras. O contraste pode ser resumido pela foto de Winogrand de um garoto prestes a colocar um amendoim na extremidade da tromba de um elefante que espera e pela foto Zoologische Garten Amsterdam II de Höfer, uma fotografia colorida de dois elefantes caminhando em direções opostas numa área parcialmente cercada, que também tem o que parecem ser "dentes" antitanque dispostos em anéis concêntricos no perímetro interno. Como é o caso em quase todas as fotografias de interiores de Höfer, em nenhum lugar de Zoologische Gärten há um ser humano à vista.
Michael Fried

Thomas Demand e suas alegorias da intenção; "exclusão" em Candida Höfer, Hiroshi Sugimoto, e Thomas Struth

65. HÖFER, Candida, Zoologische Gärten. Munich, 1993

66. *N. do T. No original, a expressão usada é take on the fly, que significa que as fotos foram tiradas durante o movimento, sem que uma cena fosse antecipadamente estudada e preparada, como se o fotógrafo fosse tirando as fotos seguidamente enquanto caminhava pelo zoológico.

67. *N. do T. A expressão usada aqui é to-be-seeness, numa tradução literal seria a característica de ser aparência.

Thomas Demand Ghost, 1995. 


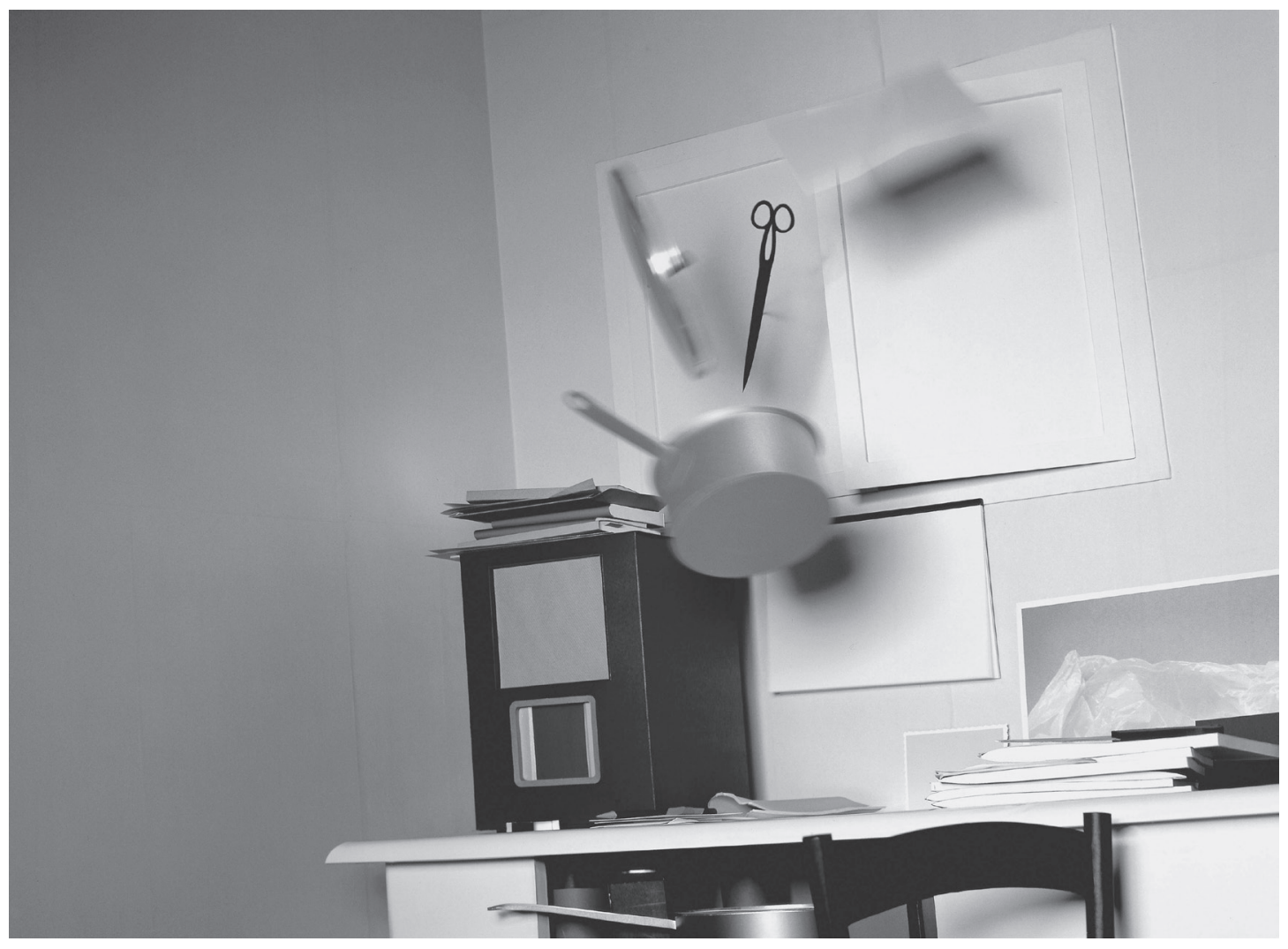

DOI: 10.11606/issn.2178-0447.

ars.2016.122442 